ISSN 0122-5383

Latin American journal of oil \& gas and alternative energies

\title{
METHODOLOGY PROPOSAL FOR CORRELATION STUDIES OF FLUVIAL SEDIMENTS BASED ON PETROGRAPHIC AND LITHOGEOCHEMICAL ANALYSIS: EXAMPLE OF ITS APPLICATION ON CENOZOIC ROCK FROM THE LISAMA FORMATION (MIDDLE MAGDALENA VALLEY, COLOMBIA)
}

\author{
PROPUESTA DE UNA METODOLOGÍA PARA ESTUDIOS DE CORRELACIÓN \\ DE SEDIMENTOS FLUVIALES A PARTIR DE ANALISIS PETROGRÁFICOS Y \\ LITOGEOQUÍMICOS: EJEMPLO DE SU APLICACIÓN EN ROCAS CENOZOICAS \\ DE LA FORMACIÓN LISAMA (VALLE MEDIO DEL MAGDALENA, COLOMBIA)
}

\author{
Julián-Francisco Naranjo-Vesga ${ }^{1 *}$, Pedro-David Gómez-Gutiérrez ${ }^{1}$, Jaime-Ricardo Gélvez-Llanez², \\ Noria-Elena Duque-Pardo ${ }^{3}$ and Néstor-Raúl Moreno-Gómez ${ }^{1}$ \\ 'Ecopetrol S.A. - Instituto Colombiano del Petróleo, A.A. 4185 Bucaramanga, Santander, Colombia \\ ${ }^{2}$ Ecopetrol S.A., Bogotá, Cundinamarca, Colombia \\ ${ }^{3}$ ANSALL LTDA, Bucaramanga, Colombia
}

e-mail: julian.naranjo@ecopetrol.com.co

(Received: Aug. 16, 2012; Accepted: Dec. 19, 2013)

\begin{abstract}
he petrographic and lithogeochemical analyses of fluvial sediments from the Lisama Formation suggest potential for the association of compositional and chemical changes of rocks with the identification and correlation of Cenozoic stratigraphic units in the Middle Magdalena valley basin. The integration of different compositional techniques enable the subdivision of the Lisama Formation into three petrographic zones. The zoning proposed herein match the palynological biozoning defined in the same stratigraphic sections, demonstrating their potential as a complementary correlation tool to biostratigraphy. This methodology of integrating petrographic and lithogeochemical analyses can be used in subsequent studies in the Middle Magdalena Basin, mainly in geographic areas where the palynomorph recovery is low or null. This work integrates Thin Section Analyses, Inductively Coupled Plasma Optical Emission Spectrometry (ICP-OES), Inductively Coupled Plasma Mass Spectrometry (ICP-MS) and X-Ray Diffraction (XRD) in two correlatable outcrops in the Western and Eastern flanks of the Nuevo Mundo Syncline (NMS).
\end{abstract}

Keywords: Lisama Formation, Petrology, Lithogeochemistry, Stratigraphic correlations, Middle Magdalena valley basin, Colombia (South America).

How to cite: Naranjo-Vesga, J. F., Gómez-Gutiérrez, P. D., Gélvez-Llanez, J. R., Duque-Pardo, N. E. \& Moreno-Gómez, N. R. (2013). Methodology proposal for correlation studies of fluvial sediments based on petrographic and lithogeochemical analysis: Example of its application on Cenozoic Rock from the Lisama Formation (Middle Magdalena Valley, Colombia). CT\&F - Ciencia, Tecnología y Futuro, 5(3), 19-46

*To whom correspondence should be addressed 


\title{
RESUMEN
}

L os análisis petrográficos y litogeoquímicos realizados en sedimentos fluviales de la Formación Lisama, sugieren un buen potencial para la asociación de cambios composicionales y químicos de las rocas con la identificación y correlación de unidades estratigráficas Cenozoicas en la cuenca del valle Medio del Magdalena. La integración de diferentes técnicas composicionales permiten la subdivisión de la Formación Lisama en tres zonas petrográficas. Las zonaciones acá propuestas tienen coincidencia con las biozonaciones palinológicas definidas en las mismas secciones estratigráficas, demostrando su potencial como herramienta de correlación complementaria a la bioestratigrafía. Esta metodología de integración de análisis petrográficos y litogeoquímicos es aplicable para posteriores estudios en la cuenca del valle Medio del Magdalena, especialmente en aquellas áreas geográficas donde el recobro de palinomorfos es bajo o ausente. En este trabajo se integraron análisis de secciones delgadas, espectrometría de emisión óptica de plasma acoplado (ICP-OES), espectrometría de masas de plasma acoplado (ICP-MS) y difracción de rayos $X(D R X)$ en dos afloramientos correlacionables a través de los flancos oriental y occidental del Sinclinal de Nuevo Mundo (SNM).

Palabras clave: Formación Lisama, Petrología, Litogeoquímica, Correlaciones estratigráficas, Cuenca del valle Medio del Magdalena, Colombia (Sur América).

\section{RESUMO}

\begin{abstract}
A
s análises petrográficas e litogeoquímicas realizadas em sedimentos fluviais da Formação Lisama, sugerem um bom potencial para a associação de mudanças composicionais e químicas das rochas com a identificação e correlação de unidades estratigráficas Cenozoícas na bacia do vale do Magdalena Médio. A integração de diferentes técnicas composicionais permite a subdivisão da Formação Lisama em três zonas petrográficas. As zonações aqui propostas têm coincidência com as biozonas palinológicas definidas nas mesmas seções estratigráficas, demonstrando seu potencial como ferramenta de correlação complementar à bioestratigrafia. Esta metodologia de integração de análises petrográficas e litogeoquímicas é aplicável para posteriores estudos na bacia do Vale do Magdalena Médio, especialmente naquelas áreas geográficas onde a recuperação de palinomorfos é baixa ou ausente. Neste trabalho foram integradas análises de seções finas, espectrometria de emissão óptica com plasma acoplado (ICP-OES), espectrometria de massas com plasma acoplado (ICP-MS) e difração de raios $X$ (DRX) em dois afloramentos correlacionados através dos flancos oriental e ocidental do Sinclinal de Nuevo Mundo (SNM).
\end{abstract}

Palavras-chave: Formação Lisama, Petrologia, Litogeoquímica, Correlações estratigráficas, Bacia do vale do Magdalena Médio, Colômbia (América do Sul). 


\section{INTRODUCTION}

In the Middle Magdalena Valley Basin (VMM), the correlation of sandy siliciclastic sediments deposited in fluvial continental environments is complex, because in this type of lithologies, recovery using conventional biostratigraphic correlation techniques is generally low. Although biostratigraphy is very useful, this article suggests an alternative, complementary correlation technique by integrating petrographic analysis, Inductively Coupled Plasma Optical Emission Spectrometry (ICP-OES), Inductively Coupled Plasma Mass Spectrometry (ICP-MS) and X-Ray Diffraction (XRD). The integration of these analytical techniques allows the subdivision of stratigraphic units in petrographic zones that can be used as a complementary correlation tool to biostratigraphy.

Therefore, the objective of this article is to show how the integration of biostratigraphic information with compositional analyses that include petrology, lithogeochemistry and XRD has potential as correlation tools in basins with the predominance of sandy lithologies where biostratigraphic recovery is difficult.

The methodology of integrating petrographic and lithogeochemical analyses can be used in subsequent studies in the Middle Magdalena Basin, mainly in geographic areas where the palynomorph recovery is low or null. This pilot study was conducted in the Lisama Formation by selecting the best correlatable outcrop columns through the Nuevo Mundo Syncline (NMS) with palynomorph recovery, in order to validate the results of the petrographic zones.

The main regional factors controlling the distribution of siliciclastic sediments deposited in fluvial and coastal continental environments are sea level, tectonics and climate variations (Catuneanu et al., 2011). These factors in turn have a high impact on sediment composition, texture and diagenesis, which is why petrographic variations can be used to identify stratigraphic units and surfaces by association of compositional, textural and diagenetic variations in rocks (Zuffa, Cibin \& Di Giulio, 1995; Kasper-Zubillaga \& Dickinson, 2001; Ketzer, Holz, Morad \& Al-Aasm, 2003; Ketzer, Morad \& Amorosi, 2003; Ketzer \&
Morad, 2006; Khidir \& Catuneanu, 2009; Morad, AlRamadan, Ketzer \& De Ros, 2010; Amorosi \& Zuffa, 2011; Kordi, Turner \& Salem, 2011; Morad, Ketzer \& De Ros, 2012).

Recently, different authors have demonstrated the relationship between the compositional and diagenetic changes in rock with sequence stratigraphy and the usefulness, thereof, as a stratigraphic correlation tool (Racey, Love, Bobolecki \& Walsh, 1995; Hussain, 2007; Amorosi \& Zuffa, 2011; Morad et al., 2012). This is possible because sediment composition and sequence stratigraphy are sensitive to the allogeneic and authigenic processes controlling sediment distribution and preservation in the stratigraphic record and the relationship between Accommodation Space (A) vs. Sediment Supply (S), Cross, (2000).

\section{GEOLOGICAL FRAMEWORK STUDY AREA}

The Middle Magdalena Valley Basin (VMM) has been subjected to major deformation events. It has a tectonically complex history, starting around the Jurassic -Late Cretaceous when there was a distensional tectonic phase. After that, from the Maastrichtian to the present, the deformational styles of compression have predominated (Cooper et al., 1995; Gómez et al., 2005). During the distensional tectonic phase, a syn-rift megasequence took place with the formation of back-arc type basins such as the Tablazo-Magdalena (Cooper et al., 1995). Transitional continental and marine sediments were deposited in this sub-basin (Fabre, 1983). Later during the Late Cretaceous-Early Paleocene, the accretion of the Western Mountain Range took place, causing a change in the tectonic regime, along with changes in the sedimentation conditions from marine environments to continental environments (Cooper et al., 1995).

The VMM basin was originated by the segmentation of an ancestral foreland basin (Cooper et al., 1995; Caballero, Parra \& Mora, 2010); it is geographically bordered on the west by the Central Mountain Range and on the east by the Eastern Mountain Range. The uplift of the Central Mountain Range occurred around the Late Cretaceous (Gómez, 2005; Caballero et al., 
2013). The tectonic inversion of the Eastern Mountain Range began in the Paleocene - Early Eocene (Mora et al., 2006; Silva et al., 2013; Caballero et al., 2013).

The deformation of the Middle Eocene enabled the formation of folds and thrusts in the VMM, which were subsequently eroded and covered with clastic sediments from the Upper Eocene (Cooper et al., 1995). Since then, the evolution of the basin has been characterized by filling with sediments from the Central and Eastern Mountain Ranges, which underwent the most deformation around the Miocene (Villamil, 1999; Sarmiento, 2001).

The NMS is a broad asymmetrical structure with a pitch to the north, located on the Western edge of the Eastern Mountain Range and in the eastern central VMM. It is bordered on the west by La Salina Fault with the tight Western flank, and angles of $70^{\circ}-80^{\circ} \mathrm{E}$. The eastern flank is smooth and extended with angles of $30^{\circ}-50^{\circ} \mathrm{W}$. This structure acquired its current configuration during the early Plio-Pleistocene deformation and contains a sedimentary wedge from the Cenozoic of more than 6000 meters (Caballero 2010; Gómez et al., 2005).

The Lisama Formation of this study is generally reported to be from the Paleocene (Figure 1), and it underlies the shallow marine to parallic lithologies of the Umir Formation. Transitional contact is documented between the two formations by the register of regressive sedimentation associated with major features from deltaic systems and alluvial plains (Gómez et al., 2005).

\section{METHODOLOGY}

The methodology covered the compositional and chemical analysis of correlatable stratigraphic columns through the Eastern and Western flank of the NMS (Figure 3). The compositional analyses were conducted in the laboratories of the Instituto Colombiano del Petróleo -ICP and consist of compositional and textural counts of petrography, XRD and whole-rock geochemical analysis (ICP-MS and ICP-OES).

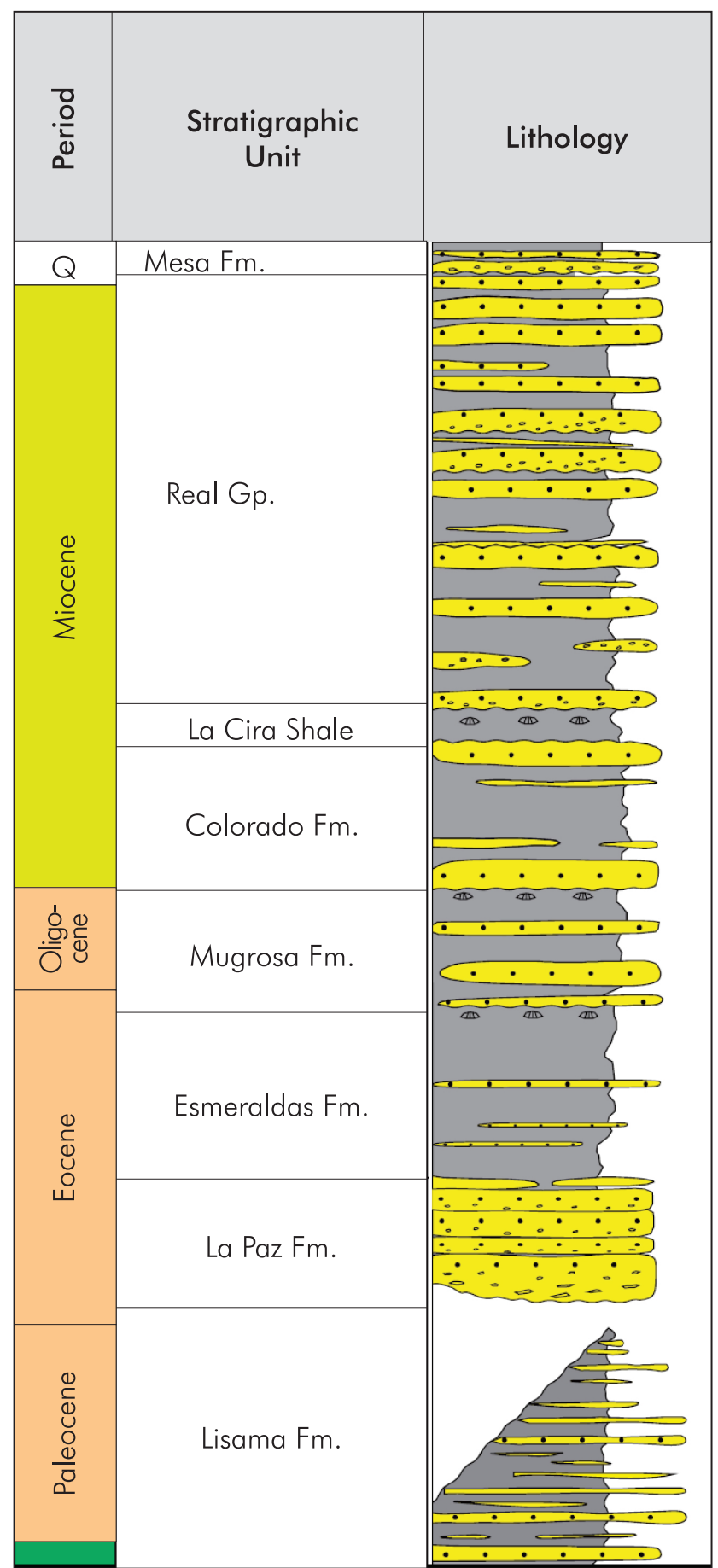

Figure 1. General stratigraphic column of the Middle Magdalena Valley modified from Barrero, Pardo, Vargas and Martínez (2007). Average thickness of Lisama Formation, $1000 \mathrm{~m}$.

These results were integrated with the analyses of stratigraphic cycles interpreted in the outcrops of interest and with the palynological biozoning defined in the sections. 
The petrological analysis of sandstones was conducted using the count from 350 to 400 points for composition following the Indiana method (Weltje, 2002) and \pm 250 points for texture. The detrital rock was classified taking into account the compositional and textural parameters of average and selection proposed by Folk (1974). Counts included a detailed description of grain types in order to determine the modal compositions and triangular diagrams of Dickinson et al. (1983 and 1985).

Geochemical analysis included the determination of the concentrations of major (10), trace (17) and rare earth elements (REE, 13) using ICP-OES Perkin Elmer 2100 DV and ICP-MS Perkin Elmer ELAN 6000. The treatment method used to analyze metals is referenced by the name CLR-LES-I-012, which is an internal methodology developed in the Spectroscopy Lab of Ecopetrol S.A. - ICP. This methodology describes the procedure for the analysis of majority metals in a closed system. In addition, this document establishes the procedure to analyze minority metals (trace metals and rare earth elements) in an open system. This methodology uses EPA 3052, ASTM D 4698 and ASTM D 1977 as a reference. The analytical results were calibrated by the systematic analysis of international standards (SCO-1, GSP-2, AGV and BIR-1A of the USGS).

Mineralogical analyses were conducted using XRD in a Siemens D500 diffractometer, with the Diffrac Plus Software to determine the mineralogical compositions of both whole rock, and the fraction lesser than 2 microns or clay fraction.

\section{RESULTS}

\section{Localization and Predominant Lithologies of the Samples Analyzed:}

In this article, lithogeochemical and petrographic characterization of the Lisama Formation in the Middle Magdalena Valley Basin in Colombia (South America) was carried out. The geographic area selected consists of two correlatable outcrops located on the Eastern and Western flanks of the NMS (Figure 2). Stratigraphic columns were uplifted in this sector (Ruiz, Gómez and
Ruiz, 2008) and they were taken as a reference for this study in which compositional analyses were conducted using petrography, XRD and whole-rock geochemistry (ICP-MS and ICP-OES). (Table 1, Table 2 and Annex 1). The biostratigraphic zoning of the columns was carried out by Rodríguez, (2009), which provided a temporary context, making it possible to compare and validate the petrographic and chemical zones. This demonstrates the potential of these techniques as a complementary correlation tool in fluvial siliciclastic sediment for the Middle Magdalena Valley Basin.

The predominant lithologies in the outcrops analyzed in the Lisama Formation are sandstones with cross-stratified trough, interspersed with laminated siltstones and mudstones. The sandy packages near the base contain poorly calibrated sets with intraclasts and floating grains that vary between medium-grained sand and gravel. The fine facies in general are multiple colors where alteration and bioturbation is common. On a local level, the sandstone is in flasser lamination and rippled in bi-directional flows, interpreting coastal channels, crevasse complexes and proximal bars, probably related to a deltaic plain with a tidal influence (Ruiz et al., 2008).

The sedimentological and ichnological analyses of the stratigraphic columns in the area under study suggest that the bottom of the Lisama Formation was deposited in an environment related to fluvial channels and interdistributary bay with tidal influence. In the middle and upper part, it is interpreted that there is a greater degree of stacking of sandy sediments associated with fluvial channels, crevasse complexes and probable proximal bars.

\section{Stratigraphy and Stratigraphic Cycles of the Lisama Formation in the Outcrops Analyzed in the Nuevo Mundo Syncline}

Ruiz et al., (2008) interpreted stratigraphic cycles of a third and fourth order in the stratigraphic columns used in this study. The methodology proposed by Cross (2000) was used for their identification, which is based on the relationship between sediment input and accommodation space $(\mathrm{A} / \mathrm{S})$, taking into account environmental variations and sediment stacking trends. This defined four maximum flood surfaces (L1M, L3M, L5M and L7M) and five minimum accommodation surfaces (L0m, L2m, L4m, L6m and L8m) (Figure 3). 


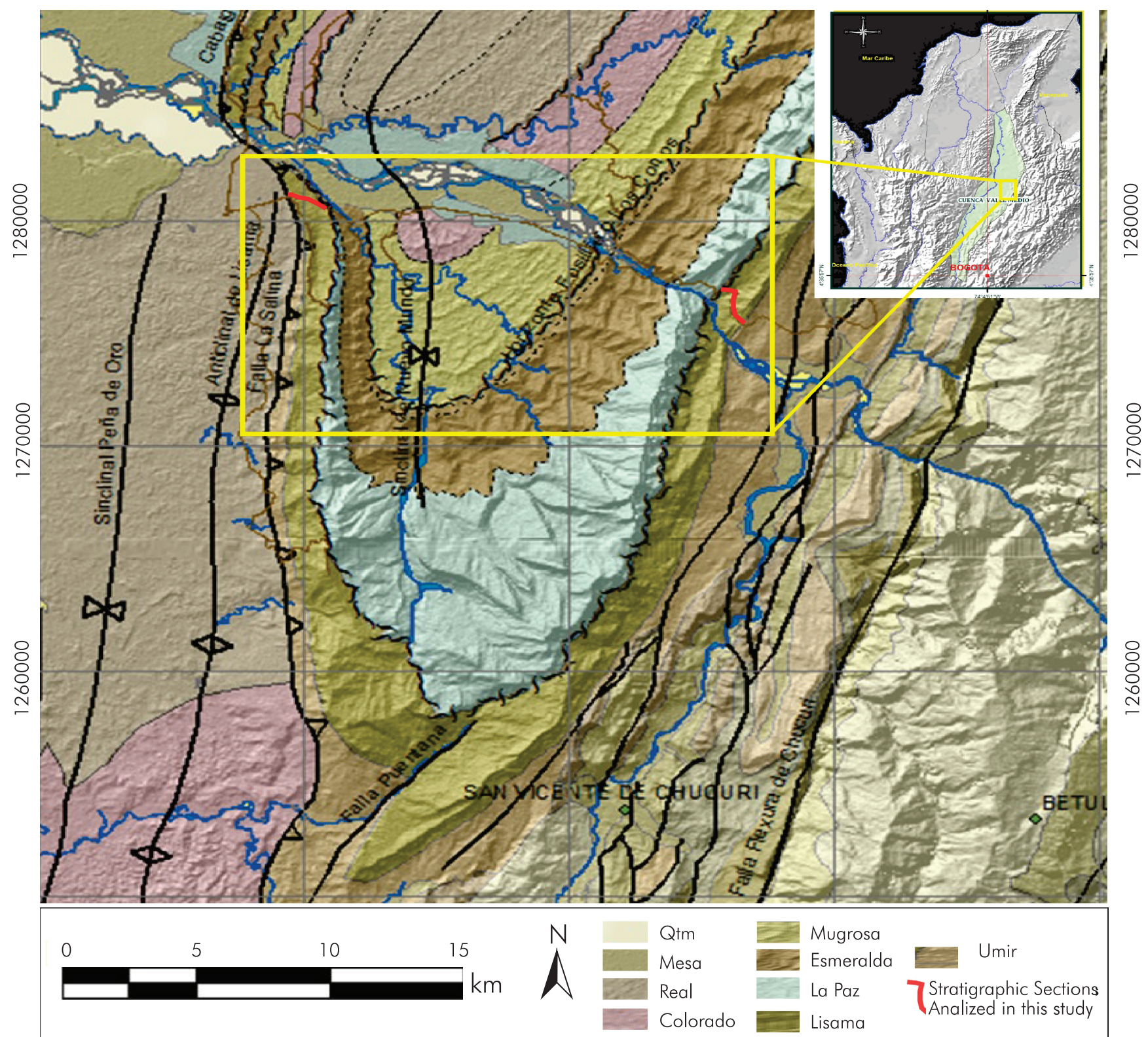

Figure 2. Location of the stratigraphic columns analyzed on the Eastern and Western flanks of the Nuevo Mundo Syncline, Middle Magdalena valley basin, Colombia, South America. Background image taken from Caballero, (2010).

\section{Biostratigraphic Dating the Lisama Formation in the Outcrops Analyzed in the Nuevo Mundo Syncline}

The biostratigraphic zoning defined for these sections (Rodríguez, 2009) associates the bottom of the sequence with Biozone E. protofranciscoi associated with the Upper Cretaceous (Maastrichtian), thus leading to the interpretation that the base of the stratigraphic sequence corresponds to the transition zone between the Umir and Lisama Formations. The middle and top of the sections are associated with Biozone B. Annae from the Paleocene (Figure 3).

\section{Integration of Results}

The integration of different petrographic techniques including thin section analysis, ICP-OES, ICP-MS and XRD enables the subdivision of the Lisama fields in three (3) petrographic zones, defined and based on the modal and chemical characteristics 
Table 1. Number of samples analyzed in the outcrop sections of the Lisama Formation, Western Flank of the Nuevo Mundo Syncline, VMM.

\begin{tabular}{|c|c|c|c|c|}
\hline \multicolumn{5}{|c|}{ Western Flank of the NMS } \\
\hline Sample & Sample Code & Petrólogy & XRD & $\begin{array}{l}\text { ICP-MS: } \\
\text { ICP-OES }\end{array}$ \\
\hline 1 & L87-01 & $x$ & $x$ & $x$ \\
\hline 2 & L73-02 & & $x$ & $x$ \\
\hline 3 & L73-01 & $x$ & $x$ & $x$ \\
\hline 4 & L71-03 & & $x$ & $x$ \\
\hline 5 & L71 -02 & $x$ & $x$ & \\
\hline 6 & $\lfloor 71-01$ & & $x$ & $x$ \\
\hline 7 & L48-01 & & $x$ & $x$ \\
\hline 8 & $\lfloor 44-01$ & $x$ & $x$ & $x$ \\
\hline 9 & L-38-01 & & $x$ & $x$ \\
\hline 10 & Ł33-01 & & $x$ & $x$ \\
\hline 11 & L32 - 02 & $x$ & $x$ & \\
\hline 12 & L22-01 & $x$ & $x$ & $x$ \\
\hline 13 & L15-01 & & $x$ & $x$ \\
\hline 14 & L1 1B-02 & & $x$ & X \\
\hline 15 & ᄂ8-01 & $x$ & $x$ & \\
\hline 16 & L7-06 & $x$ & & $x$ \\
\hline 17 & L7-05 & & $x$ & $x$ \\
\hline 18 & L7-03 & & $x$ & $x$ \\
\hline 19 & L7-02 & & $x$ & $x$ \\
\hline 20 & L7-01 & & $x$ & $x$ \\
\hline 21 & L6-02 & & $x$ & $x$ \\
\hline 22 & L6-01 & $x$ & $x$ & $x$ \\
\hline 23 & L5-02 & $x$ & $x$ & $x$ \\
\hline 24 & L5-01 & $x$ & $x$ & $x$ \\
\hline 25 & L4-02 & $x$ & $x$ & $x$ \\
\hline 26 & $\lfloor 4-01$ & & $x$ & $x$ \\
\hline 27 & L3-02 & & $x$ & $x$ \\
\hline 28 & L3-01 & $x$ & & $x$ \\
\hline 29 & L2-01 & & $x$ & \\
\hline 30 & L1 -04 & & $x$ & \\
\hline 31 & L1 -03 & & $x$ & $x$ \\
\hline 32 & L1-02 & $x$ & $x$ & $x$ \\
\hline 33 & L1-01 & & $x$ & $x$ \\
\hline
\end{tabular}

Table 2. Number of samples analyzed in the outcrop sections of the Lisama Formation, Eastern Flank of the Nuevo Mundo Syncline, VMM.

\begin{tabular}{|c|c|c|c|c|}
\hline \multicolumn{5}{|c|}{ Eastern Flank of the NMS } \\
\hline Sample & Sample Code & Petrólogy & XRD & $\begin{array}{l}\text { ICP-MS: } \\
\text { ICP-OES }\end{array}$ \\
\hline 1 & CB100-02 & & $x$ & $x$ \\
\hline 2 & CB100-01 & $x$ & & \\
\hline 3 & CB99-01 & $x$ & & \\
\hline 4 & CB77-02 & & $x$ & $x$ \\
\hline 5 & CB77-01 & $x$ & $x$ & \\
\hline 6 & CB60-03 & $x$ & $x$ & \\
\hline 7 & CB60-01 & $x$ & $x$ & $x$ \\
\hline 8 & CB44-01 & $x$ & $x$ & $x$ \\
\hline 9 & СВ35-01 & & $x$ & $x$ \\
\hline 10 & CB34-04 & & $x$ & $x$ \\
\hline 11 & CB34-03 & $x$ & $x$ & $x$ \\
\hline 12 & CB34-02 & & $x$ & $x$ \\
\hline 13 & CB34-01 & $x$ & $x$ & $x$ \\
\hline 14 & CB33-01 & $x$ & $x$ & $x$ \\
\hline 15 & CB32-02 & $x$ & $x$ & $x$ \\
\hline 16 & CB32-01 & $x$ & $x$ & \\
\hline 17 & CB27-01 & $x$ & $x$ & $x$ \\
\hline 18 & CB25-02 & & $x$ & \\
\hline 19 & CB25-01 & & $x$ & $x$ \\
\hline 20 & CB24-02 & & $x$ & $x$ \\
\hline 21 & CB24-01 & & $x$ & $x$ \\
\hline 22 & CB22-02 & $x$ & & \\
\hline 23 & CB21-01 & $x$ & $x$ & $x$ \\
\hline 24 & CB9-01 & $x$ & $x$ & $x$ \\
\hline 25 & CB3-01 & $x$ & $x$ & $x$ \\
\hline 26 & CB2-02 & & $x$ & $x$ \\
\hline 27 & CB2-01 & $x$ & $x$ & \\
\hline 28 & CB1-03 & $x$ & $x$ & \\
\hline 29 & CB 1-02 & & $x$ & $x$ \\
\hline 30 & CB1-01 & & $x$ & $x$ \\
\hline 31 & CBO-01 & $x$ & $x$ & $x$ \\
\hline
\end{tabular}




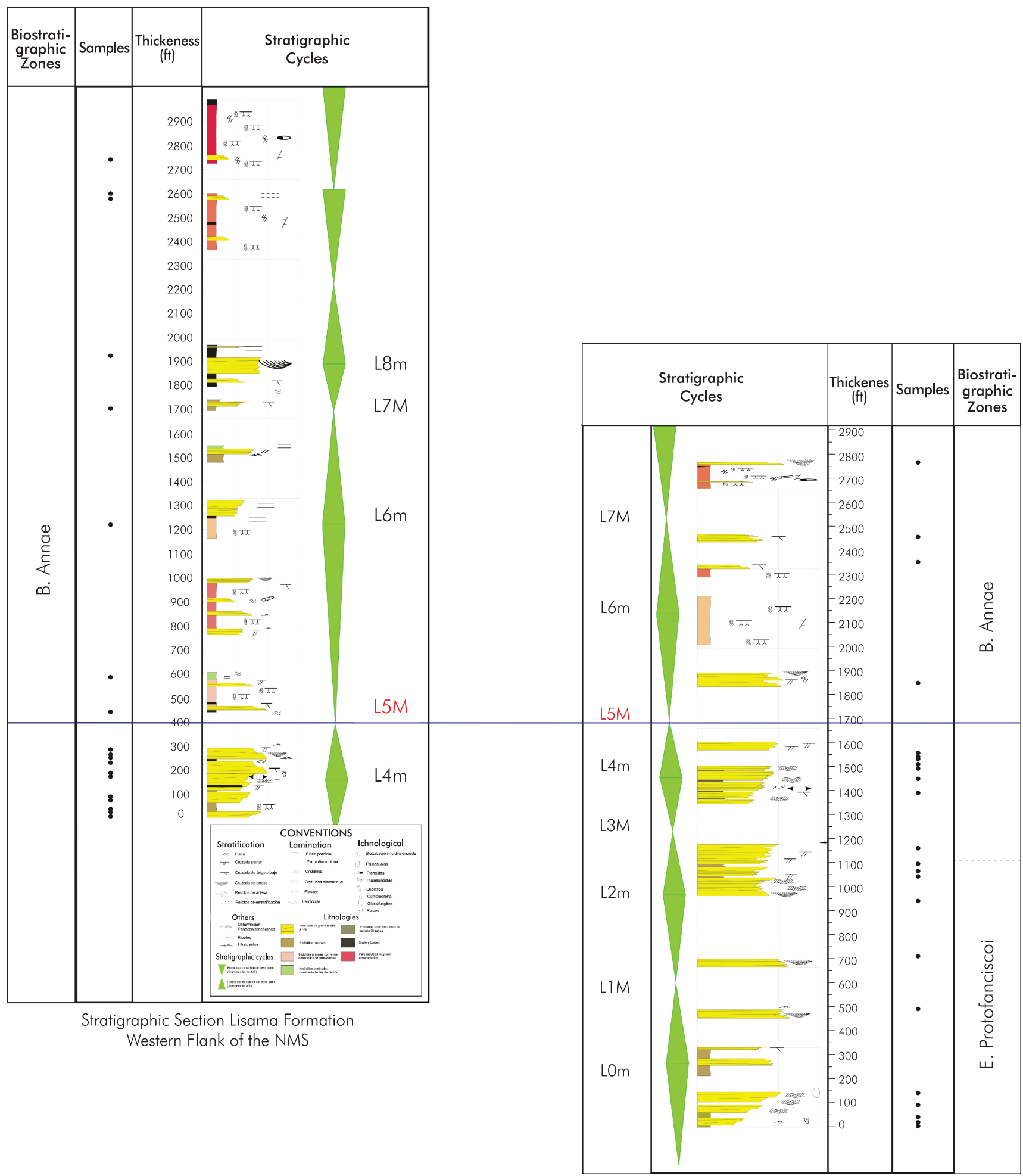

Stratigraphic Section Lisama Formation Eastern Flank of the NMS

Figure 3. Stratigraphic cycles and biostratigraphic zoning suggested for the columns in the Lisama Formation on the Western and Eastern flanks of the NMS. Modified from Ruiz et al. (2008). 
of the rocks, known as Lisama A, B and C. Due to the better preservation of the stratigraphic column of the Lisama Formation on the Eastern flank of the NMS, both the petrographic and the lithogeochemical zones are more complete and better defined on this flank (Figures 4 and 5).

\section{Lisama A Zone}

Petrographically, it is characterized by a high lithic content $\left(\mathrm{Q}_{45}, \mathrm{~F}_{9}, \mathrm{~L}_{46}\right)$. The quartz and rock fragments of a volcanic and sedimentary origin are the main components of the framework; there are also feldspars and glauconite to a lesser proportion.

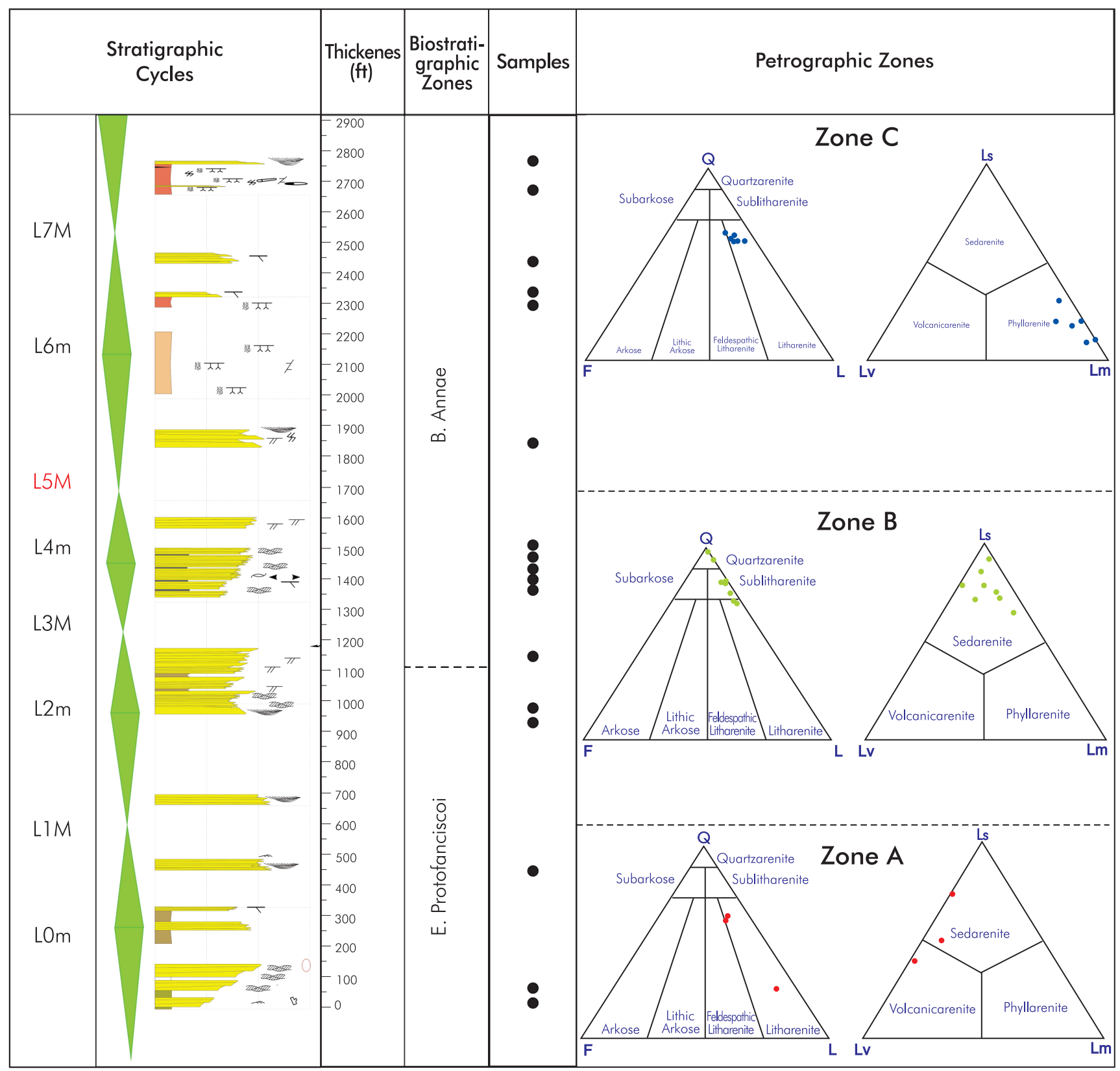

Petrographic Zones Lisama Formation, Eastern Flank NMS Mundo.

Figure 4. Petrographic zones defined in the column of the Lisama Formation in the eastern sector of the Nuevo Mundo Syncline. $Q=$ Total $Q u a r t z ;$ $\mathrm{F}=$ Total Feldspar; $\mathrm{L}=$ Total Lithics; Ls= Sedimentary Lithics; Lv = Volcanic Lithics; Lm = Metamorphic Lithics. Modified from Ruiz et al. (2008). 


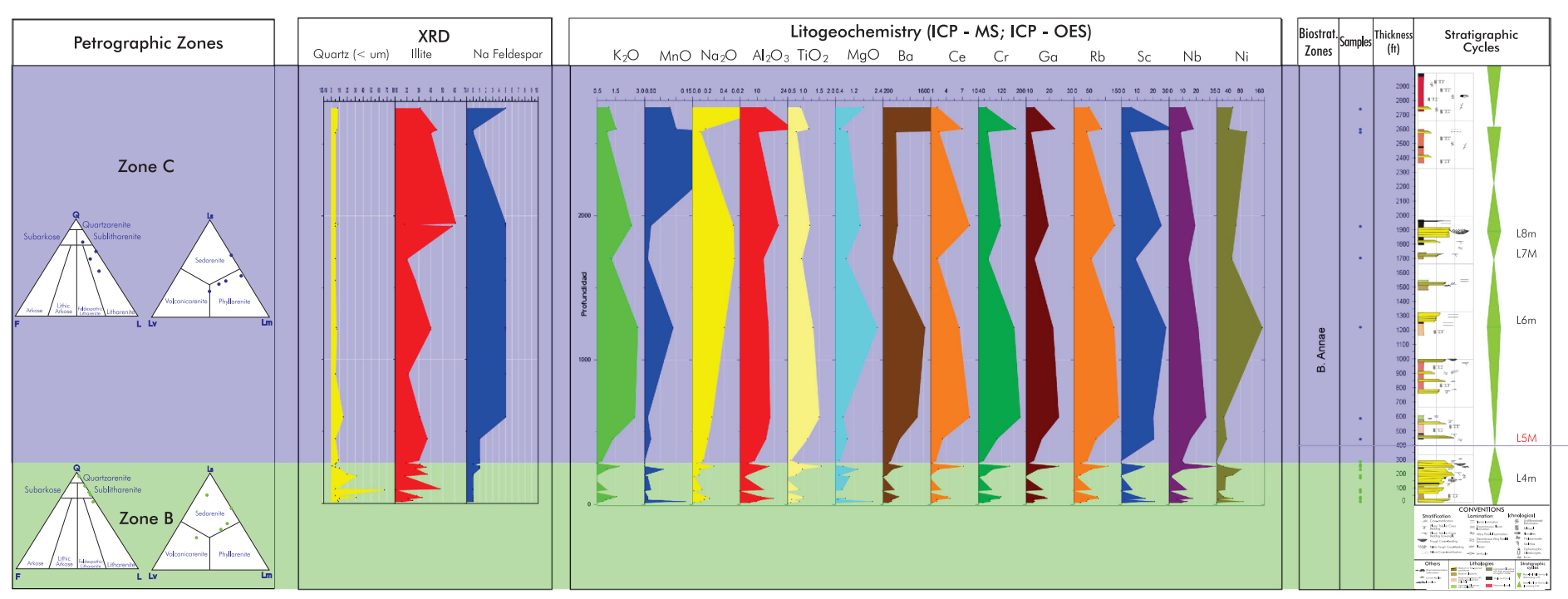

Figure 5. Integration of stratigraphic cycles, biostratigraphic areas and compositional zones for the stratigraphic correlation of the Lisama Formation on the Western and Eastern flanks of the Nuevo Mundo Syncline. Modified from Ruiz et al. (2008). 


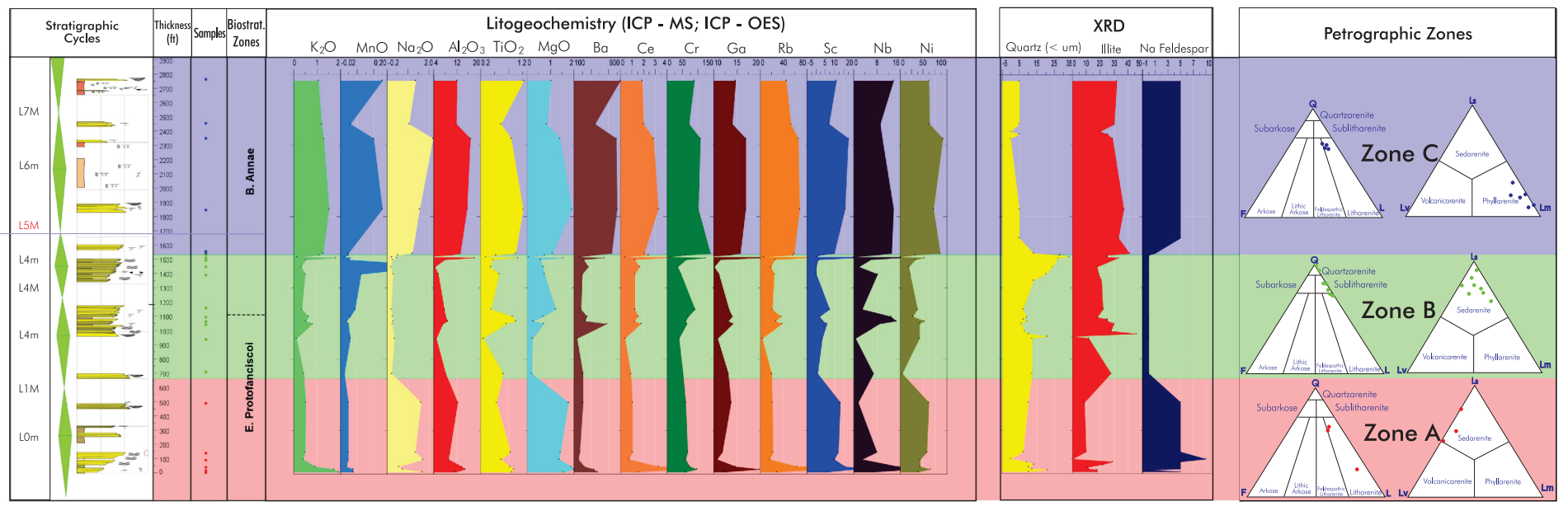


Compositionally, they are classified as litharenites and feldespathic Litharenites. This area is predominated by sedimentary and volcanic lithics sub-classified as sedarenite and volcarenite, according to Folk (1974). Chemically, it is characterized by having generally low concentrations of $\mathrm{Ba}, \mathrm{Ce}, \mathrm{Cr}, \mathrm{Ga}, \mathrm{Rb}, \mathrm{Nb}, \mathrm{K}_{2} \mathrm{O}$ and $\mathrm{MnO}$. Inversely, there is enrichment of $\mathrm{Na}_{2} \mathrm{O}, \mathrm{Al}_{2}, \mathrm{TiO}_{2}$, $\mathrm{MgO}, \mathrm{Sc}$ and $\mathrm{Ni}$. Similarly, XRD analyses associate this interval with low illite and quartz content, and high percentages of sodium feldspar (Figure 5 and Annex 1).

\section{Lisama B Zone}

The middle zone of the Lisama Formation is characterized by a marked decrease in lithic content $\left(\mathrm{Q}_{84}, \mathrm{~F}_{2}\right.$, $\left.\mathrm{L}_{14}\right)$. Compositionally, they are classified as quartzarenite and sublitharenite (Folk, 1974); predominant lithics are sedimentary, so they are sub-classified as sedarenite (Figure 4).

Chemically, this interval is similar to zone A, although there is a marked depletion of $\mathrm{Ni}, \mathrm{Sc}, \mathrm{MgO}, \mathrm{Al}_{2} \mathrm{O}_{3}$ and $\mathrm{Na}_{2} \mathrm{O}$ concentrations (Figure 5 and Annex 1). XRD values suggest a comparative enrichment in zone A of the illite and quartz content and, inversely, a depletion in sodium feldspar (Figure 5 and Annex 1).

\section{Lisama C Zone}

The top of the section is petrographically characterized by the increase in lithics $\left(\mathrm{Q}_{64}, \mathrm{~F}_{7}, \mathrm{~L}_{30}\right)$, and the predominance of metamorphic rock fragments. Compositionally, they are classified as litharenites and feldespathic litharenites, and sub-classified as phyllarenite (Figure 4) according to Folk (1974).

Chemically, it shows enrichment of the major elements, particularly $\mathrm{K}_{2} \mathrm{O}, \mathrm{MnO}, \mathrm{Na}_{2} \mathrm{O}, \mathrm{Al}_{2} \mathrm{O}_{3}, \mathrm{TiO}_{2}$ and $\mathrm{MgO}$. In addition, the concentrations of $\mathrm{Ba}, \mathrm{Ce}, \mathrm{Cr}, \mathrm{Ga}$, $R b, S c, N b$ and $N$ have increased (Figure 5 and Annex 1). At the same time, the values of illite and sodium feldspar have increased in XRD; inversely, quartz contents have decreased in this zone.

\section{Interpretation of Petrographical and Lithogeochemi- cal Data in the Outcrops Analyzed of the Lisama Formation in the Nuevo Mundo Syncline}

The rocks from the lower interval (Zone A) are characterized by low compositional maturity, as evidenced by the predominance of volcanic and sedimentary lithics. Plagioclase prevails in this interval over potassium feldspar, suggesting the influence of sinsedimentary volcanism or the presence of important volcanic lithotypes in the source area. The influence of volcanogenic debris in this segment and probable magmatic activity is also recognized in the chemical compositions of the sediment, as illustrated in the diagram differentiating the types of source rock proposed by Roser and Korsch (1986), in which the lithologies from this interval are associable with Active Continental Margins (ACM) (Figure 6). The sedimentary lithics are interpreted as recycled sediments originated during the initial stages of orogenic dismantling caused by the tectonic inversion of the Mesozoic extensional basin during the early Paleocene (Mora et al., 2006; Silva et al., 2013; Caballero et al., 2013).

In the middle and upper part of the Lisama Formation (Zones $\mathrm{B}$ and $\mathrm{C}$ ), the nature of the lithics varies considerably with respect to Zone A with the predominance of Sedimentary and low to medium metamorphic fragments, schists and metagranitc lithic. Chemically, these segments also are differentiated from the previous zone and their origin is associated with Passive Margins (PM), according to the classification of Roser and Korsch (1986) (Figure 6).

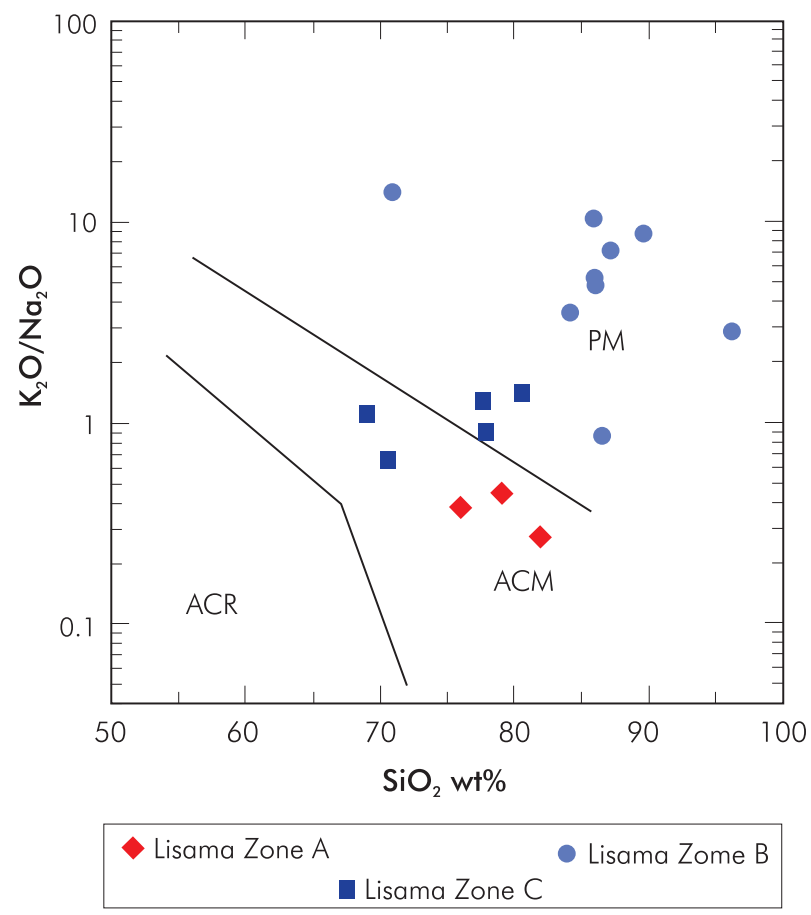

Figure 6. Discriminatory diagrams of source rock type for the Lisama Formation; PM = Passive Margin; ACM = Active Continental Margin; $A R C=$ Magmatic Arc; based on the classification proposed by Roser and Korsch (1986). 


\section{CONCLUSIONS}

- The petrographic zones defined for the Lisama Formation in the Middle Magdalena Valley in general match the biostratigraphic zoning, suggesting potential for implementation as an Alternative stratigraphic correlation technique. This methodology of integrating petrographic and lithogeochemical analyses can be used in subsequent studies in the Middle Magdalena Basin, mainly in geographic areas where the palynomorph recovery is low or null.

- Lower Zone A of the Lisama Formation is characterized by its high lithic content $\left(\mathrm{Q}_{45}, \mathrm{~F}_{9}, \mathrm{~L}_{46}\right)$, mainly of a volcanic and sedimentary origin; chemically, this lower segment has low concentrations of $\mathrm{Ba}, \mathrm{Ce}, \mathrm{Cr}$, $\mathrm{Ga}, \mathrm{Rb}, \mathrm{Nb}, \mathrm{K}_{2} \mathrm{O}$ and $\mathrm{MnO}$. Inversely, the concentrations of $\mathrm{Na}_{2} \mathrm{O}, \mathrm{Al}_{2} \mathrm{O}_{3}, \mathrm{TiO}_{2}, \mathrm{MgO}, \mathrm{Sc}$ and $\mathrm{Ni}$ are high. This zone has the input of sedimentary and volcanic debris associated with sinsedimentary volcanism and the orogenic dismantling caused by the tectonic inversion of the Mesozoic extensional basin during the early Paleocene. Sediments in this zone were deposited in environments related to fluvial channels and interdistributary bays with tidal influence.

- The middle of the formation or Petrographic Zone B is identified by the marked decrease in lithic content $\left(\mathrm{Q}_{84}, \mathrm{~F}_{2}, \mathrm{~L}_{14}\right)$, predominated by those of a sedimentary origin. Chemically, this interval is similar to zone A, although there is a marked depletion of $\mathrm{Ni}, \mathrm{Sc}, \mathrm{MgO}$, $\mathrm{Al}_{2} \mathrm{O}_{3}$ and $\mathrm{Na}_{2} \mathrm{O}$. The presence of sedimentary lithics is associated with the erosion of the sedimentary Mesozoic or Paleozoic rock cover. This zone has the most stacking of sandy sediments associated with fluvial channels, crevasse complexes and probable proximal bars, showing greater shallowing and energy in the environment compared with the underlying zone.

- Finally, Zone $\mathrm{C}$ is characterized by the increase in lithics $\left(\mathrm{Q}_{64}, \mathrm{~F}_{7}, \mathrm{~L}_{30}\right)$ mainly metamorphic in origin; chemically, it shows enrichment of the major elements $\mathrm{K}_{2} \mathrm{O}, \mathrm{MnO}, \mathrm{Na}_{2} \mathrm{O}, \mathrm{Al}_{2} \mathrm{O}_{3}, \mathrm{TiO}_{2}$ and $\mathrm{MgO}$. In addition, the concentrations of $\mathrm{Ba}, \mathrm{Ce}, \mathrm{Cr}, \mathrm{Ga}, \mathrm{Rb}, \mathrm{Sc}, \mathrm{Nb}$ and $\mathrm{Ni}$ have increased. The source area suggests sediment inputs from levels in the metamorphic domains. In this zone, the percentages of $\mathrm{K}_{2} \mathrm{O}, \mathrm{MnO}, \mathrm{Na}_{2} \mathrm{O}, \mathrm{TiO}_{2}$ and $\mathrm{MgO}$ increase, reason for which it is associated with environmental conditions of greater meteorization of the sediment following their deposition, which coincides with the greater preservation of facies associated with paleosols near the top of the stratigraphic column analyzed. There is also a marked increase in the concentrations of $\mathrm{Ce}, \mathrm{Cr}, \mathrm{Ga}, \mathrm{Rb}, \mathrm{Sc}, \mathrm{Nb}$ and $\mathrm{Ni}$; these elements are associated with changes in sediment source rock (Pearce et al., 2010 a, b; Ractliffe et al., 2004).

- The integrated use of lithogeochemical and petrographic techniques has helped improve the presence and correlation of stratigraphic cycles, showing great usefulness in the correlation of formations with low resolution in biostratigraphy, as well as in zones with partial rock exposure.

\section{ACKNOWLEDGEMENTS}

The authors would like to express their gratitude to the Spectrometry and XRD Laboratories of the Instituto Colombiano del Petróleo (ICP) for conducting the compositional analyses. They would also like to thank the Sub-Andean Basin Project for its financial support and approbation for the publication of this paper.

\section{REFERENCES}

Amorosi, A. \& Zuffa, G. (2011). Sand composition changes across key boundaries of siliciclastic and hybrid depositional sequences. Sedimentary Geology, 236(1-2), 153-163.

ASTM D 4698. Sample Preparation, Total Digestion of Sediment Samples for Chemical Analysis of Various Metals, Annual Book of Standards, ASTM International.

Barrero, D., Pardo, A., Vargas, C. A. \& Martínez, J. F. (2007). Colombian Sedimentary Basins: nomenclature, Boundaries and Petroleum Geology, a New Proposal. Bogotá: Agencia Nacional de Hidrocarburos.

Caballero, V. (2010). Evolución tectono-sedimentaria del sinclinal de Nuevo Mundo, cuenca sedimentaria Valle Medio del Magdalena Colombia, durante el Oligoceno - Mioceno. Tesis de maestría, Escuela de Geología, Universidad Industrial de Santander, Bucaramanga, Colombia, 157pp.

Caballero, V., Parra, M. \& Mora A. (2010). Levantamiento de la cordillera oriental de Colombia durante el Eoceno 
Tardío - Oligoceno temprano: Proveniencia sedimentaria en el sinclinal de nuevo mundo, cuenca valle Medio del Magdalena. Boletín Geológico, 32(1), 45-77.

Caballero, V., Parra, M., Mora, A., López, C., Rojas, L. E. \& Quintero, I. (2013). Factors controlling selective abandonment and reactivation in thick skin orogens: a case study in the Magdalena Valley, Colombia. Geological Society, London, Special Publications, 377: 343-367.

Catuneanu, O., Galloway, W., Kendall, C., Miall, A., Posamentier, H., Strasser, A. \& Tucker, M. (2011). Sequence Stratigraphy: Methodology and Nomenclature. Newsl. Stratigr., 44(3), 173-245.

Cooper, M. A., Addison, F. T., Álvarez, R., Coral, M., Graham, R. H., Hayward, A. B., Howe, S., Martínez, J., Naar, J., Peñas, R., Pullham, A. J. \& Taborda, A. (1995). Basin development and tectonic history of the Llanos Basin, Eastern Cordillera and Middle Magdalena Valley, Colombia. AAPG Bulletin, 79(10), 1421-1443.

Cross, T. A. (2000). Stratigraphic controls on reservoir attributes in continental strata. ESF, 7(4), 320-350.

Dickinson, W. R., Beard, L. S., Brakenridge, G. R., Erjavec, J. L., Ferguson, R. C., Inman, K. F., Knepp, R. A., Lindberg, F. A. \& Ryberg, P. T. (1983). Provenance of North American Phanerozoic sandstones in relation to tectonic setting. Geol. Soc. Amer. Bull., 94(2), 222-235.

Dickinson, W. R. (1985). Interpreting provenance relations from detrital modes of sandstones. In: Zuffa G. G. (ed.), Provenance of Arenites, Netherlands: Springer Netherlands, 148: 333-361.

Fabre, A. (1983). La subsidencia de la Cuenca del Cocuy (Cordillera Oriental de Colombia) durante el Cretáceo y el Terciario inferior. Segunda parte: Esquema de evolución tectónica. Geología Norandina, 8: 21-27.

Folk, R. (1974). Petrology of sedimentary rocks. Austin: Hemphill Publishing Co.

Gómez, E., Jordan, T. E., Allmendinger, R. W., Hegarty, K. \& Kelley, S. (2005). Syntectonic Cenozoic sedimentation in the Northern Middle Magdalena Valley Basin of Colombia and implications for exhumation of the Northern Andes. Geol. Soc. Amer. Bull., 117(5/6), 547-569.

Hussain, M. (2007). Elemental chemistry as a tool of stratigraphic correlation: A case study involving lower Paleozoic Wajid, Saq, and Qasim Formations in Saudi Arabia. Mar. Petrol. Geol., 24(2), 91-108.
Kasper-Zubillaga, J. J. \& Dickinson, W. (2001). Discriminating depositional environments of sands from modern source terrains using modal analysis. Sedimentary Geology, 143: 149-167.

Ketzer, J. \& Morad, S. (2006). Predictive distribution of shallow marine, low-porosity (pseudomatrix-rich) sandstones in a sequence stratigraphic framework -example from the Ferron sandstone, Upper Cretaceous, USA. Mar. Petrol. Geol., 23(1), 29-36.

Ketzer, J. M., Holz, M., Morad, S. \& Al-Aasm, I. S. (2003). Sequence stratigraphic distribution of diagenetic alterations in coal-bearing, parallic sandstones: evidence from the Rio Bonito Formation (early Permian), southern Brazil. Sedimentology, 50(5), 855-877.

Ketzer, J., Morad, S. \& Amorosi, A. (2003). Predictive diagenetic clay-mineral distribution in siliciclastic rocks within a sequence stratigraphic framework. In: Worden, R. H. \& Morad, S. (Eds): Clay Mineral Cements in Sandstones. International Association of Sedimentologists Special Publication 34, Oxford: Blackwell Publication, 43-61.

Khidir, A. \& Catuneanu, O. (2009). Predictive diagenetic clay-mineral distribution in siliciclastic rocks as a tool for identifying sequence boundaries in non/marine successions: the Coalspur Formation, west-central Alberta. Geologos, 15(3-4), 169-180.

Kordi, M., Turner, B. \& Salem, A. (2011). Linking diagenesis to sequence stratigraphy in fluvial and shallow marine sandstones: Evidence from the Cambriane Ordovician lower sandstone unit in Southwestern Sinai, Egypt. Mar. Petrol. Geol., 28: 1554-1571.

Mora, A., Parra, M., Strecker, M. R., Kammer, A., Dimaté, C. \& Rodríguez, F. (2006). Cenozoic contractional reactivation of Mesozoic extensional structures in the Eastern Cordillera of Colombia. Tectonics, 25(2), 1-19.

Morad, S., Al-Ramadan, K., Ketzer, J. M. \& De Ros, L. F. (2010). The impact of diagenesis on the heterogeneity of sandstone reservoirs: A review of the role of depositional facies and sequence stratigraphy. AAPG Bulletin, 94(8), 1267-1309.

Morad, S., Ketzer, J. M. \& De Ros, L. F. (2012). Linking Diagenesis to Sequence Stratigraphy. International Association of Sedimentologist, IAS. Special Publication 45, Malaysia: Wiley-Blackwell.

Pearce, T., Martin, J., Cooper, D. \& Wray, D. (2010a). Chemostratigraphy of upper carboniferous (Pennsylvanian) 
sequences from the Southern North sea (United Kingdom). In: Ratcliffe, K. \& Zaitlin, B. Application of modern stratigraphic techniques: Theory and case histories. Tulsa: SEPM Special Publication, 94: 109-127.

Pearce, T., Mclean, D., Martin, J., Ractliffe, K. \& Wray, D. (2010b). A whole-rock geochemical approach to the recognition and correlation of "Marine Bands". In: Ratcliffe, K. \& Zaitlin, B. Application of modern stratigraphic techniques: Theory and case histories. Tulsa: SEPM Special Publication 94, 221-238.

Racey, A., Love, M. A., Bobolecki, R. M. \& Walsh, J. N. (1995). The use of chemical element analyses in the study of biostratigraphically barren sequences: an example from the Triassic of the Central North sea (UKCS). Geological Society, London, Special Publications, 89: 69-105.

Ratcliffe, K. T., Wright, A. M., Montgomery, P., Palfrey, A., Vonk, A., Vermeulen, J. \& Barrett, M. (2010). Application of chemostratigraphy to the Mungaroo Formation, the Gorgon Field, offshore Northwest Australia. APPEA J., 50th Anniversary Issue: 371-388.

Rodríguez, G. (2009). Información bioestratigráfica del Cenozoico de la Cuenca Valle Medio del Magdalena. Informe Técnico, Ecopetrol S.A. - Instituto Colombiano del Petróleo (ICP).

Roser, B. P. \& Korsch, R. J. (1986). Determination of tectonic setting of sandstone-mudstone suites using $\mathrm{SiO}_{2}$ content and $\mathrm{K}_{2} \mathrm{O} / \mathrm{Na}_{2} \mathrm{O}$ ratio. Journal Geology, 94(5), 635-650.

Ruiz, C., Gómez, P. \& Ruiz, A. (2008). Levantamiento estratigráfico de la Formación Lisama, en el área del Sinclinal del Nuevo Mundo, Cuenca del Valle Medio del Magdalena. Informe Técnico, Ecopetrol S.A. - Instituto Colombiano del Petróleo (ICP).

Sarmiento, L. F. (2001). Mesozoic Rifting and Cenozoic Basin inversion history of the Eastern Cordillera, Colombian Andes. Inference from tectonic models. Disertación Doctoral, Universidad de Amsterdam, Amsterdam 295pp.

Silva, A., Mora, A., Caballero, V., Rodríguez, G., Ruiz, C., Moreno, N., Parra, M., Ramírez, J., Ibañez, M. \& Quintero, I. (2013). Basin compartmentalization and drainage evolution during rift inversion; evidence from the Eastern Cordillera of Colombia. Geological Society, London, Special Publications, 377.

Ver Straeten, C., Brett, C. \& Sageman, B. (2011). Mudrock sequence stratigraphy: A multi-proxy (sedimentological, paleobiological and geochemical) approach, Devonian
Appalachian Basin. Palaeogeogr. Palaeoclimat. Palaeoecol., 304(1-2), 54-73.

Villamil, T. (1999). Campanian-Miocene tectonostratigraphy, depocenter evolution and basin development of Colombia and Western Venezuela. Palaeogeogr. Palaeoclimat. Palaeoecol., 153(1-4), 239-275.

Weltje, G. (2002). Quantitative analysis of detrital modes: Statistically rigorous confidence regions in ternary diagrams and their use in sedimentary petrology. Earth Sci. Rev. 57: 211-253.

Wright, A. M., Ratcliffe, K. T., Zaitlin, B. A. \& Wray, D. S. (2010). The application of chemostratigraphic techniques to distinguish compound incised valleys in low accommodation incised valley systems in a foreland basin setting: an example from the Lower Cretaceous Mannville Group and Basal Colorado Sandstone (Colorado Group), Western Canadian Sedimentary Basin. In: Ratcliffe, K. \& Zaitlin, B.. Application of modern stratigraphic techniques: Theory and case histories. Tulsa: SEPM Special Publication, 94: 93-108.

Zuffa, G. G, Cibin, U. \& Di Giulio, A. (1995). Arenite petrography in sequence stratigraphy. J. Geology, 103:451-459.

\section{AUTHORS}

\section{Julián-Francisco Naranjo-Vesga}

Afiliación: Ecopetrol S.A. - Instituto Colombiano del Petróleo. Geologist, Universidad Industrial de Santander.

M. Sc., National University of Ireland.

e-mail: julian.naranjo@ecopetrol.com.co

\section{Pedro-David Gómez-Gutiérrez}

Afiliación: Ecopetrol S.A. - Instituto Colombiano del Petróleo.

Geologist, Universidad Industrial de Santander.

e-mail: pedroda.gomez@ecopetrol.com.co

\section{Jaime-Ricardo Gélvez-Llanez}

Afiliación: Ecopetrol S.A.

Geologist, Universidad Industrial de Santander.

M. Sc. in Geoscience, Shimane University.

e-mail: jaime.gelvez@ecopetrol.com.co

Noria-Elena Duque-Pardo

Afiliación: ANSALL LTDA.

Geologist, Universidad Industrial de Santander.

e-mail: noriaduque@gmail.com

\section{Néstor-Raúl Moreno-Gómez}

Afiliación: Ecopetrol S.A. - Instituto Colombiano del Petróleo.

Geologist, Universidad Industrial de Santander.

e-mail: nestor.moreno@ecopetrol.com.co 


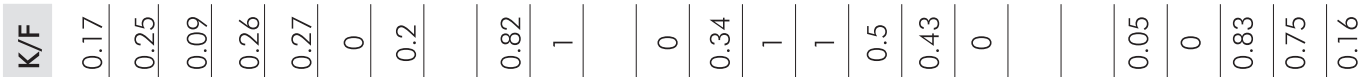

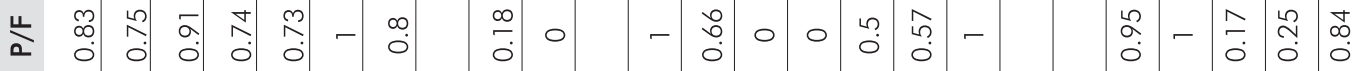

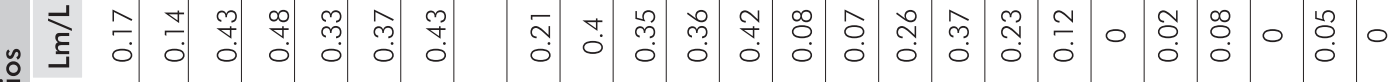

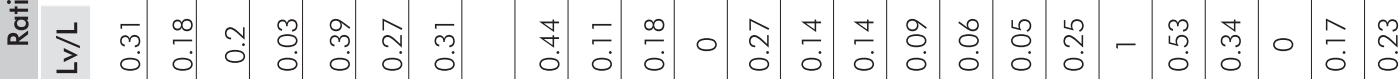
立

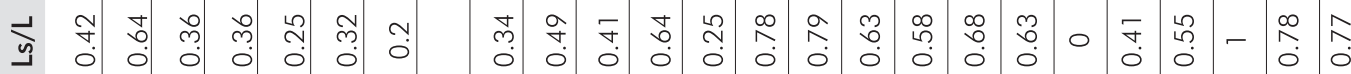
- J 0 . ت $\dot{j}$ ஸे б. 产 है

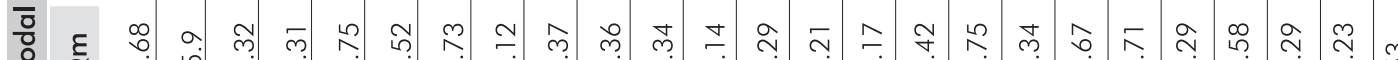
方

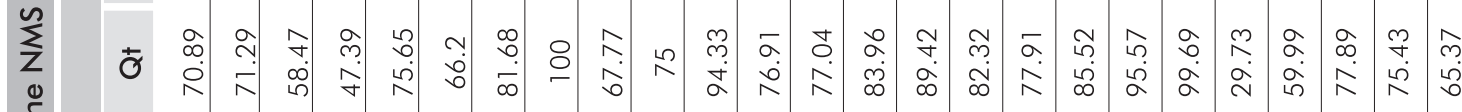
는

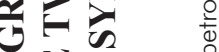

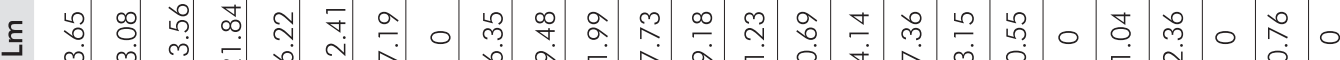

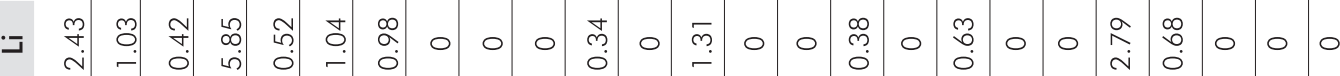

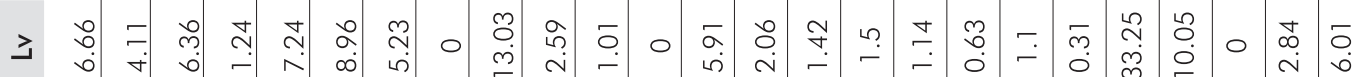
y 0 .

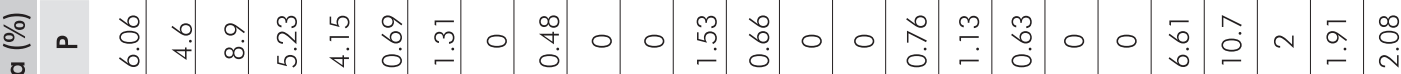

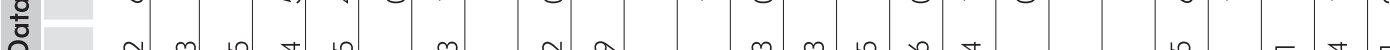

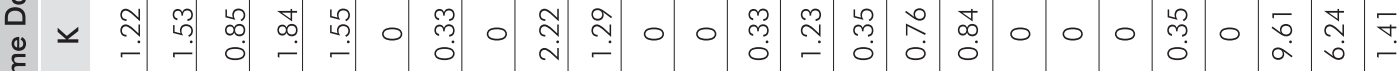

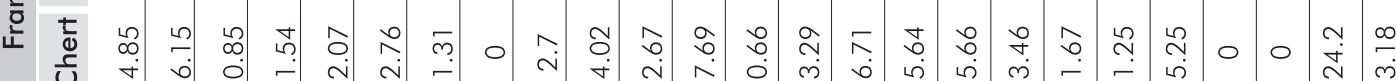

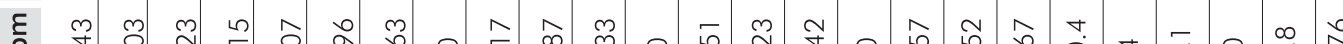
वे

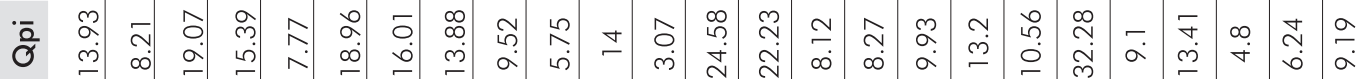
$\begin{array}{lllllllllllllllllllllllllll}0 & 0 & 0 & 0 & 0 & 0 & 0 & 0 & 0 & 0 & 0 & 0 & 0 & 0 & 0 & 0 & 0 & 0 & 0 & 0 & 0 & 0 & 0 & 0 & 0 & 0\end{array}$ $\varepsilon \quad 0 \quad 0 . j)$ ○

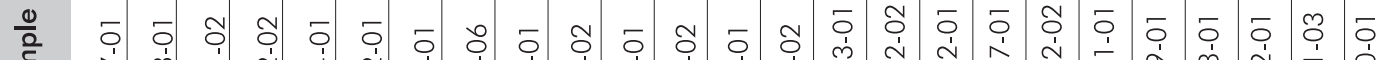
它 


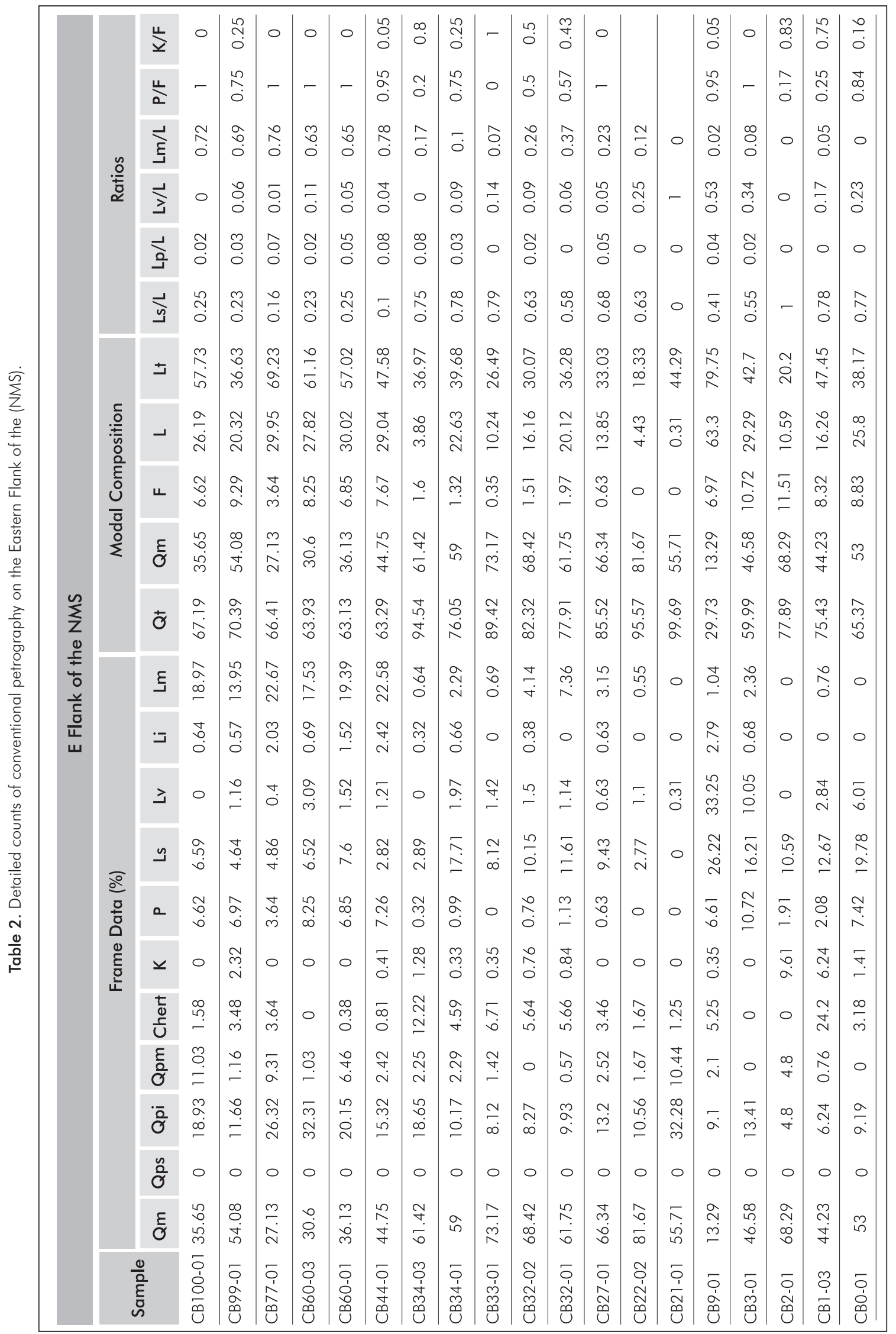


Table 3. Results of the XRD analysis of the total fraction on the Western Flank of the (NMS).

\begin{tabular}{|c|c|c|c|c|c|c|c|c|}
\hline \multicolumn{9}{|c|}{ W Flank of the NMS } \\
\hline Sample & Clay & Quartz & Feldspar (K) & Feldspar ( $\mathrm{Na})$ & Carbonates & Gypsum & Pyrite & Others \\
\hline L87-01 & 15 & 70 & ND & $<5$ & ND & ND & $<5$ & $<5$ \\
\hline L73-02 & 36 & 59 & ND & ND & ND & ND & ND & $<5$ \\
\hline L73-01 & 9 & 79 & ND & ND & 7 & ND & ND & $<5$ \\
\hline L71-03 & 30 & 60 & ND & $<5$ & ND & ND & ND & $<5$ \\
\hline L71-02 & 25 & 65 & ND & $<5$ & ND & ND & ND & $<5$ \\
\hline L71-01 & 38 & 52 & ND & $<5$ & ND & ND & ND & $<5$ \\
\hline L48-01 & 15 & 75 & ND & $<5$ & ND & ND & ND & $<5$ \\
\hline L44-01 & 15 & 75 & ND & $<5$ & ND & ND & ND & $<5$ \\
\hline L-38-01 & 42 & 38 & $<5$ & $<5$ & ND & $<5$ & ND & $<5$ \\
\hline L33-01 & 30 & 55 & $<5$ & $<5$ & ND & ND & ND & $<5$ \\
\hline L32-02 & 20 & 60 & $<5$ & $<5$ & ND & ND & 5 & $<5$ \\
\hline L22-01 & 10 & 80 & ND & $<5$ & ND & ND & ND & $<5$ \\
\hline L15-01 & 40 & 45 & $<5$ & $<5$ & $\operatorname{Tr}$ & ND & ND & $<5$ \\
\hline L1 1 B-02 & 27 & 68 & ND & $\mathrm{Tr}$ & ND & ND & ND & $<5$ \\
\hline L8-01 & 40 & 45 & $<5$ & $<5$ & ND & ND & ND & $<5$ \\
\hline L7-05 & 15 & 80 & $\operatorname{Tr}$ & $\mathrm{Tr}$ & $\operatorname{Tr}$ & ND & ND & $<5$ \\
\hline L7-03 & 25 & 65 & $<5$ & $\mathrm{Tr}$ & ND & ND & ND & $<5$ \\
\hline L7-02 & 6 & 89 & ND & ND & ND & ND & ND & $<5$ \\
\hline L7-01 & 45 & 50 & $\operatorname{Tr}$ & $\mathrm{Tr}$ & $\operatorname{Tr}$ & ND & ND & $<5$ \\
\hline L6-02 & 25 & 60 & $\operatorname{Tr}$ & $\mathrm{Tr}$ & $<5$ & ND & $<5$ & $<5$ \\
\hline L6-01 & 20 & 70 & $\operatorname{Tr}$ & $\mathrm{Tr}$ & $<5$ & ND & ND & $<5$ \\
\hline L5-02 & 7 & 88 & ND & ND & $\operatorname{Tr}$ & ND & ND & $<5$ \\
\hline L5-01 & $<5$ & 90 & ND & ND & ND & ND & ND & $<5$ \\
\hline L4-02 & 21 & 74 & ND & ND & $\mathrm{Tr}$ & ND & ND & $<5$ \\
\hline L4-01 & $<5$ & 90 & ND & ND & ND & ND & ND & $<5$ \\
\hline L3-02 & 15 & 80 & ND & ND & ND & ND & ND & $<5$ \\
\hline L2-01 & 20 & 70 & ND & $\mathrm{Tr}$ & $<5$ & ND & $\operatorname{Tr}$ & $<5$ \\
\hline L1 -04 & 23 & 72 & ND & ND & ND & $N D$ & ND & $<5$ \\
\hline L1-03 & 12 & 83 & ND & ND & $\operatorname{Tr}$ & ND & ND & $<5$ \\
\hline L1-02 & 13 & 77 & ND & ND & $<5$ & ND & ND & $<5$ \\
\hline L1-01 & 5 & 90 & ND & ND & ND & ND & ND & $<5$ \\
\hline
\end{tabular}


Table 4. Results of the XRD analysis of the total fraction on the Eastern Flank of the (NMS).

\begin{tabular}{|c|c|c|c|c|c|c|c|c|}
\hline \multicolumn{9}{|c|}{ E Flank of the NMS } \\
\hline Sample & Clay & Quartz & Feldspar (K) & Feldspar $(\mathrm{Na})$ & Carbonates & Gypsum & Pyrite & Others \\
\hline CB100-02 & 10 & 80 & ND & $<5$ & ND & ND & ND & $<5$ \\
\hline CB77-02 & 30 & 50 & ND & 5 & $<5$ & ND & $<5$ & $<5$ \\
\hline CB77-01 & 20 & 65 & ND & 5 & ND & ND & $<5$ & $<5$ \\
\hline CB60-03 & 25 & 55 & ND & $<5$ & 5 & ND & $<5$ & $<5$ \\
\hline CB60-01 & 15 & 75 & ND & $<5$ & ND & ND & ND & $<5$ \\
\hline CB44-01 & 19 & 66 & ND & $<5$ & ND & ND & $<5$ & $<5$ \\
\hline CB35-01 & 25 & 65 & $\operatorname{Tr}$ & $<5$ & ND & ND & ND & $<5$ \\
\hline CB34-04 & 10 & 85 & ND & $\operatorname{Tr}$ & ND & $\operatorname{Tr}$ & ND & $<5$ \\
\hline CB34-03 & $<5$ & 90 & ND & ND & ND & ND & ND & $<5$ \\
\hline CB34-02 & 25 & 60 & $<5$ & ND & ND & $<5$ & ND & $<5$ \\
\hline CB34-01 & 16 & 79 & ND & ND & ND & ND & ND & $<5$ \\
\hline CB33-01 & 5 & 80 & ND & ND & 5 & $<5$ & ND & $<5$ \\
\hline CB32-02 & 5 & 75 & ND & ND & $<5$ & $<5$ & $<5$ & $<5$ \\
\hline CB32-01 & 6 & 84 & ND & ND & $\mathrm{Tr}$ & $<5$ & ND & $<5$ \\
\hline CB27-01 & 21 & 74 & ND & ND & ND & ND & ND & $<5$ \\
\hline CB25-02 & 35 & 60 & ND & ND & ND & ND & ND & $<5$ \\
\hline CB25-01 & 6 & 89 & ND & ND & ND & ND & ND & $<5$ \\
\hline CB24-02 & 9 & 86 & $\operatorname{Tr}$ & ND & ND & ND & ND & $<5$ \\
\hline CB24-01 & 8 & 87 & $\operatorname{Tr}$ & ND & ND & ND & ND & $<5$ \\
\hline CB21-01 & $<5$ & 90 & ND & ND & ND & ND & ND & $<5$ \\
\hline CB9-01 & 25 & 65 & ND & $<5$ & ND & ND & ND & $<5$ \\
\hline CB3-01 & 20 & 70 & ND & $<5$ & ND & ND & ND & $<5$ \\
\hline CB2-02 & 13 & 73 & ND & 9 & ND & ND & ND & $<5$ \\
\hline CB2-01 & 12 & 50 & ND & $<5$ & 28 & ND & ND & $<5$ \\
\hline CB1-03 & 20 & 65 & ND & $<5$ & $<5$ & ND & ND & $<5$ \\
\hline CB 1-02 & 15 & 70 & $<5$ & $<5$ & ND & ND & ND & $<5$ \\
\hline CB 1-01 & 20 & 70 & ND & $<5$ & ND & ND & ND & $<5$ \\
\hline CB0-01 & 14 & 76 & ND & 5 & ND & ND & ND & $<5$ \\
\hline
\end{tabular}


Table 5. Results of the XRD analysis of the $<5 \mu \mathrm{m}$ fraction on the Western Flank of the (NMS).

\begin{tabular}{|c|c|c|c|c|c|c|}
\hline \multicolumn{7}{|c|}{ W Flank of the NMS } \\
\hline Sample & Smectites & Chlorites & Interstrat & Illite & Kaolinite & Quartz \\
\hline L87-01 & ND & 28 & ND & 31 & 33 & 8 \\
\hline L73-02 & 13 & ND & ND & 45 & 35 & 7 \\
\hline L73-01 & 7 & 13 & ND & 40 & 35 & 5 \\
\hline L71-03 & 5 & 8 & ND & 61 & 21 & 5 \\
\hline L71 -02 & 12 & & ND & 18 & 62 & 8 \\
\hline L71-01 & ND & 20 & ND & 58 & 17 & 5 \\
\hline$\lfloor 48-01$ & ND & 22 & ND & 20 & 53 & 5 \\
\hline L44-01 & 10 & 28 & ND & 27 & 30 & 5 \\
\hline L-38-01 & 5 & 24 & ND & 40 & 25 & 6 \\
\hline L33-01 & ND & 16 & ND & 40 & 37 & 7 \\
\hline L32-02 & ND & 8 & ND & 19 & 73 & ND \\
\hline L22-01 & 9 & ND & ND & 21 & 65 & 5 \\
\hline L15-01 & ND & ND & 12 & 31 & 42 & 15 \\
\hline L1 1B-02 & ND & 17 & ND & 37 & 41 & 5 \\
\hline L8-01 & ND & 6 & ND & 36 & 53 & 5 \\
\hline L7-05 & ND & 6 & ND & 30 & 55 & 9 \\
\hline L7-03 & ND & ND & ND & 19 & 75 & 6 \\
\hline L7-02 & ND & ND & ND & 31 & 64 & 5 \\
\hline L7-01 & ND & ND & 7 & 33 & 60 & ND \\
\hline L6-02 & ND & 6 & ND & 36 & 53 & 5 \\
\hline L6-01 & ND & 8 & ND & 27 & 55 & 10 \\
\hline L5-02 & ND & ND & ND & 37 & 43 & 20 \\
\hline L5-01 & ND & ND & ND & 18 & 50 & 32 \\
\hline$\llcorner 4-02$ & ND & ND & ND & 48 & 47 & 5 \\
\hline$\lfloor 4-01$ & ND & ND & ND & 11 & 22 & 67 \\
\hline L3-02 & ND & ND & ND & 28 & 67 & 5 \\
\hline L2-01 & ND & 10 & 12 & 33 & 40 & 5 \\
\hline L1 -04 & ND & ND & ND & 33 & 36 & 31 \\
\hline L1-03 & ND & 8 & ND & 21 & 61 & 10 \\
\hline L1 -02 & ND & 11 & ND & 25 & 56 & 8 \\
\hline L1-01 & ND & ND & ND & 16 & 75 & 9 \\
\hline
\end{tabular}


Table 6. Results of the XRD analysis of the $<5 \mu \mathrm{m}$ fraction on the Eastern Flank of the (NMS).

\begin{tabular}{|c|c|c|c|c|c|c|}
\hline \multicolumn{7}{|c|}{ E Flank of the NMS } \\
\hline Sample & Smectites & Chlorites & Interstrat & Illite & Kaolinite & Quartz \\
\hline CB100-02 & ND & 21 & ND & 32 & 42 & 5 \\
\hline CB77-02 & 6 & 9 & 25 & 30 & 25 & 5 \\
\hline CB77-01 & 8 & ND & ND & 20 & 72 & ND \\
\hline CB60-03 & ND & 48 & ND & 25 & 22 & 5 \\
\hline CB60-01 & ND & ND & ND & 29 & 71 & ND \\
\hline CB44-01 & ND & 6 & 20 & 37 & 32 & 5 \\
\hline CB35-01 & ND & 11 & 23 & 33 & 28 & 5 \\
\hline CB34-04 & ND & 20 & ND & 41 & 26 & 13 \\
\hline CB34-03 & ND & ND & ND & 25 & 47 & 28 \\
\hline CB34-02 & ND & 18 & ND & 25 & 24 & 33 \\
\hline CB34-01 & ND & 9 & ND & 33 & 31 & 27 \\
\hline СВ33-01 & ND & 37 & ND & 18 & 21 & 24 \\
\hline CB32-02 & ND & 34 & ND & 19 & 27 & 20 \\
\hline CB32-01 & ND & 19 & 26 & 21 & 21 & 13 \\
\hline CB27-01 & ND & 34 & ND & 22 & 37 & 7 \\
\hline CB25-02 & ND & 28 & 23 & 18 & 22 & 9 \\
\hline CB25-01 & 18 & 28 & ND & 25 & 22 & 7 \\
\hline CB24-02 & ND & 8 & 18 & 25 & 40 & 9 \\
\hline CB24-01 & ND & 15 & 23 & 30 & 26 & 6 \\
\hline CB21-01 & ND & ND & 55 & 12 & 21 & 12 \\
\hline CB9-01 & ND & ND & 27 & 9 & 54 & 10 \\
\hline CB3-01 & ND & 35 & 9 & 10 & 39 & 7 \\
\hline CB2-02 & ND & 34 & ND & ND & 66 & ND \\
\hline CB2-01 & ND & 33 & 6 & 29 & 23 & 9 \\
\hline CB1-03 & ND & 38 & 7 & 22 & 20 & 13 \\
\hline CB 1-02 & ND & ND & 60 & 11 & 19 & 10 \\
\hline CB1-01 & ND & 38 & 24 & 12 & 14 & 12 \\
\hline СB0-01 & ND & 27 & 13 & 18 & 32 & 10 \\
\hline
\end{tabular}


Table 7. Values of major elements calculated with ICP-OES on the Western Flank of the (NMS).

\begin{tabular}{|c|c|c|c|c|c|c|c|c|c|c|c|}
\hline \multicolumn{12}{|c|}{ W Flank of the NMS } \\
\hline Sample & $\mathrm{SiO}_{2}$ & $\mathrm{TiO}_{2}$ & $\mathrm{Al}_{2} \mathrm{O}_{3}$ & $\mathrm{Fe}_{2} \mathrm{O}_{3} \mathrm{~T}$ & $\mathrm{MnO}$ & $\mathrm{MgO}$ & $\mathrm{CaO}$ & $\mathrm{Na}_{2} \mathrm{O}$ & $\mathrm{K}_{2} \mathrm{O}$ & $\mathrm{P}_{2} \mathrm{O}_{5}$ & SUM \\
\hline L87-01 & 76.71 & 0.92 & 13.75 & 3.81 & 0.08 & 1.60 & 0.87 & 1.00 & 1.15 & 0.12 & 100.00 \\
\hline L73-02 & 62.84 & 1.17 & 26.67 & 1.09 & 0.10 & 0.61 & 5.68 & 0.17 & 1.51 & 0.16 & 100.00 \\
\hline L73-01 & 72.88 & 0.79 & 10.39 & 3.00 & 0.35 & 0.92 & 10.44 & 0.11 & 1.03 & 0.09 & 100.00 \\
\hline L71 -03 & 75.41 & 0.41 & 19.13 & 2.85 & 0.57 & 0.97 & 0.19 & 0.07 & 0.36 & 0.04 & 100.00 \\
\hline L71-01 & 68.99 & 1.21 & 19.76 & 4.62 & 0.02 & 1.46 & 0.59 & 0.52 & 2.33 & 0.49 & 100.00 \\
\hline L48-01 & 80.64 & 0.95 & 12.81 & 1.93 & 0.01 & 0.86 & 0.78 & 0.53 & 1.28 & 0.20 & 100.00 \\
\hline L44-01 & 77.76 & 1.01 & 13.35 & 4.63 & 0.09 & 0.47 & 0.22 & 0.60 & 1.46 & 0.40 & 100.00 \\
\hline L-38-01 & 67.41 & 1.31 & 15.31 & 7.49 & 0.09 & 2.18 & 2.09 & 0.41 & 2.66 & 1.04 & 100.00 \\
\hline Ł33-01 & 72.44 & 1.06 & 14.57 & 6.35 & 0.03 & 1.52 & 0.52 & 1.35 & 2.07 & 0.09 & 100.00 \\
\hline L22-01 & 83.77 & 0.58 & 10.17 & 2.95 & 0.04 & 0.64 & 0.25 & 0.57 & 0.98 & 0.04 & 100.00 \\
\hline L15-01 & 76.45 & 1.50 & 15.88 & 2.24 & 0.01 & 0.74 & 0.34 & 0.25 & 2.49 & 0.11 & 100.00 \\
\hline L1 1 B-02 & 78.56 & 1.12 & 14.02 & 3.54 & 0.02 & 0.91 & 0.10 & 0.20 & 1.36 & 0.18 & 100.00 \\
\hline L7-05 & 88.51 & 0.61 & 8.89 & 0.38 & 0.00 & 0.59 & 0.10 & 0.14 & 0.78 & 0.00 & 100.00 \\
\hline L7-03 & 92.48 & 0.85 & 5.48 & 0.27 & 0.00 & 0.14 & 0.11 & 0.07 & 0.51 & 0.10 & 100.00 \\
\hline L7-02 & 90.55 & 0.57 & 7.26 & 0.26 & 0.00 & 0.53 & 0.11 & 0.12 & 0.60 & 0.00 & 100.00 \\
\hline L7-01 & 78.23 & 1.57 & 15.55 & 1.11 & 0.00 & 0.73 & 0.69 & 0.28 & 1.67 & 0.17 & 100.00 \\
\hline L6-02 & 74.80 & 0.80 & 13.70 & 3.80 & 0.04 & 1.68 & 3.44 & 0.15 & 1.35 & 0.25 & 100.00 \\
\hline L6-01 & 77.43 & 0.98 & 12.02 & 4.70 & 0.06 & 1.34 & 2.10 & 0.10 & 1.07 & 0.19 & 100.00 \\
\hline L5-02 & 91.40 & 0.78 & 5.32 & 0.26 & 0.00 & 0.59 & 1.09 & 0.09 & 0.46 & 0.00 & 100.00 \\
\hline L5-01 & 93.02 & 0.40 & 4.13 & 1.07 & 0.01 & 0.99 & 0.09 & 0.03 & 0.26 & 0.00 & 100.00 \\
\hline L4-02 & 80.85 & 0.86 & 13.23 & 2.30 & 0.02 & 0.69 & 0.75 & 0.13 & 1.04 & 0.14 & 100.00 \\
\hline$\lfloor 4-01$ & 97.22 & 0.31 & 1.77 & 0.16 & 0.00 & 0.13 & 0.17 & 0.02 & 0.12 & 0.11 & 100.00 \\
\hline L3-02 & 84.20 & 0.99 & 11.95 & 0.84 & 0.01 & 0.01 & 0.17 & 0.17 & 1.54 & 0.12 & 100.00 \\
\hline L2-01 & 73.55 & 1.17 & 15.63 & 4.51 & 0.03 & 1.27 & 1.63 & 0.29 & 1.69 & 0.24 & 100.00 \\
\hline L1-04 & 77.78 & 0.99 & 17.63 & 0.87 & 0.01 & 0.85 & 0.43 & 0.22 & 1.21 & 0.02 & 100.00 \\
\hline L1-03 & 83.64 & 0.64 & 11.99 & 1.60 & 0.01 & 0.51 & 0.33 & 0.15 & 1.00 & 0.14 & 100.00 \\
\hline L1-02 & 72.74 & 0.89 & 9.78 & 11.46 & 0.13 & 1.98 & 1.93 & 0.11 & 0.82 & 0.16 & 100.00 \\
\hline L1-01 & 90.22 & 0.60 & 6.49 & 1.57 & 0.00 & 0.25 & 0.34 & 0.03 & 0.41 & 0.10 & 100.00 \\
\hline
\end{tabular}


Table 8. Values of major elements calculated with ICP-OES on the Eastern Flank of the (NMS).

\begin{tabular}{|c|c|c|c|c|c|c|c|c|c|c|c|}
\hline \multicolumn{12}{|c|}{ E Flank of the NMS } \\
\hline Sample & $\mathrm{SiO}_{2}$ & $\mathrm{TiO}_{2}$ & $\mathrm{Al}_{2} \mathrm{O}_{3}$ & $\mathrm{Fe}_{2} \mathrm{O}_{3} \mathrm{~T}$ & $\mathrm{MnO}$ & $\mathrm{MgO}$ & $\mathrm{CaO}$ & $\mathrm{Na}_{2} \mathrm{O}$ & $\mathrm{K}_{2} \mathrm{O}$ & $\mathrm{P}_{2} \mathrm{O}_{5}$ & SUM \\
\hline CB100-02 & 77.89 & 1.14 & 12.18 & 4.54 & 0.18 & 1.05 & 0.59 & 1.16 & 1.06 & 0.22 & 100.00 \\
\hline CB77-02 & 80.61 & 0.65 & 11.94 & 3.27 & 0.03 & 0.85 & 0.57 & 0.85 & 1.21 & 0.00 & 100.00 \\
\hline CB60-01 & 70.68 & 0.87 & 16.67 & 5.80 & 0.14 & 1.42 & 0.91 & 1.97 & 1.31 & 0.24 & 100.00 \\
\hline CB44-01 & 68.96 & 1.12 & 15.44 & 8.04 & 0.18 & 1.93 & 1.21 & 1.37 & 1.52 & 0.24 & 100.00 \\
\hline CB35-01 & 77.72 & 0.97 & 13.21 & 4.34 & 0.02 & 1.09 & 0.30 & 1.00 & 1.28 & 0.07 & 100.00 \\
\hline CB34-04 & 84.17 & 0.54 & 9.79 & 2.76 & 0.02 & 0.77 & 0.50 & 0.31 & 1.09 & 0.06 & 100.00 \\
\hline CB34-03 & 96.27 & 0.32 & 2.47 & 0.42 & 0.00 & 0.06 & 0.18 & 0.05 & 0.15 & 0.09 & 100.00 \\
\hline CB34-02 & 71.89 & 1.01 & 18.00 & 4.03 & 0.03 & 1.55 & 1.07 & 0.29 & 1.81 & 0.32 & 100.00 \\
\hline CB34-01 & 87.16 & 0.48 & 7.92 & 2.75 & 0.02 & 0.58 & 0.47 & 0.07 & 0.53 & 0.02 & 100.00 \\
\hline CB33-01 & 70.97 & 0.42 & 4.64 & 2.46 & 0.49 & 0.71 & 19.84 & 0.02 & 0.33 & 0.12 & 100.00 \\
\hline CB32-02 & 86.05 & 0.60 & 5.64 & 3.36 & 0.08 & 0.76 & 2.86 & 0.09 & 0.49 & 0.06 & 100.00 \\
\hline CB27-01 & 79.94 & 0.44 & 7.73 & 9.88 & 0.05 & 1.23 & 0.33 & 0.02 & 0.37 & 0.00 & 100.00 \\
\hline CB25-01 & 86.90 & 0.89 & 8.16 & 2.52 & 0.03 & 0.71 & 0.08 & 0.07 & 0.65 & 0.00 & 100.00 \\
\hline CB24-02 & 86.09 & 0.97 & 9.02 & 2.84 & 0.01 & 0.27 & 0.13 & 0.11 & 0.52 & 0.04 & 100.00 \\
\hline CB24-01 & 85.91 & 0.76 & 7.42 & 3.75 & 0.02 & 0.72 & 0.29 & 0.08 & 0.80 & 0.25 & 100.00 \\
\hline CB21-01 & 86.55 & 0.27 & 4.93 & 7.46 & 0.03 & 0.23 & 0.21 & 0.16 & 0.14 & 0.01 & 100.00 \\
\hline CB9-01 & 76.00 & 0.55 & 12.45 & 6.22 & 0.02 & 1.78 & 0.89 & 1.43 & 0.54 & 0.13 & 100.00 \\
\hline CB3-01 & 79.04 & 0.85 & 9.63 & 6.42 & 0.02 & 1.45 & 0.79 & 1.15 & 0.51 & 0.15 & 100.00 \\
\hline CB2-02 & 81.89 & 0.65 & 9.20 & 4.05 & 0.02 & 1.38 & 0.83 & 1.51 & 0.41 & 0.06 & 100.00 \\
\hline CB1-02 & 79.69 & 0.83 & 13.62 & 1.72 & 0.01 & 1.89 & 0.92 & 0.38 & 0.92 & 0.02 & 100.00 \\
\hline CB1-01 & 73.85 & 0.92 & 14.90 & 4.88 & 0.04 & 2.05 & 1.01 & 0.55 & 1.73 & 0.07 & 100.00 \\
\hline CBO-01 & 74.62 & 0.88 & 11.73 & 4.09 & 0.04 & 1.58 & 3.50 & 1.49 & 1.92 & 0.14 & 100.00 \\
\hline
\end{tabular}




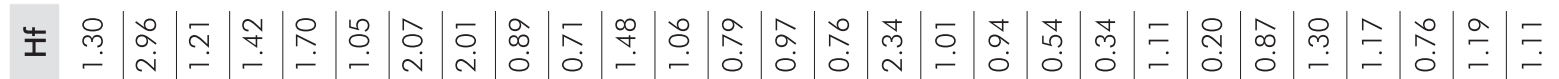

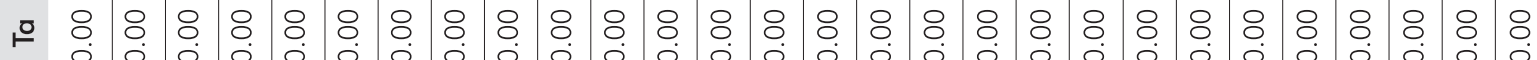

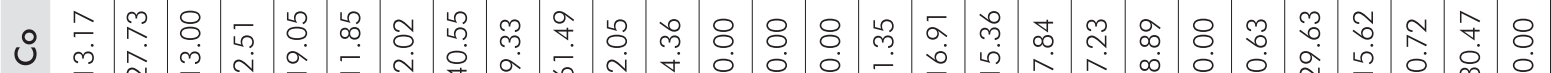

$\supset$

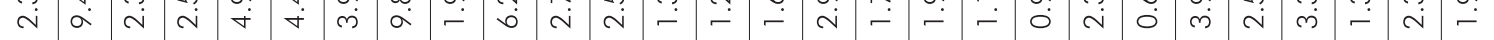

-

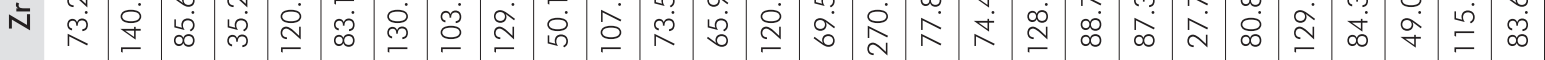

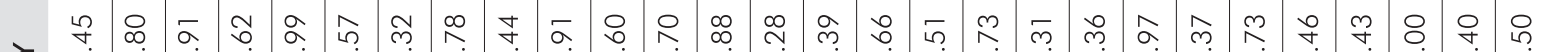

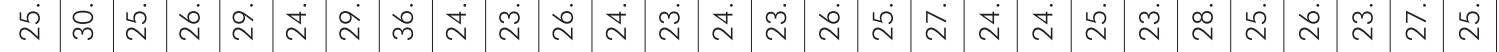

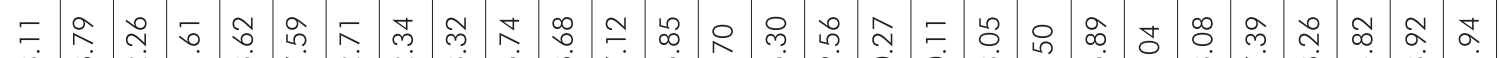

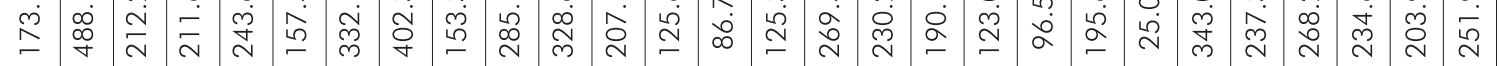

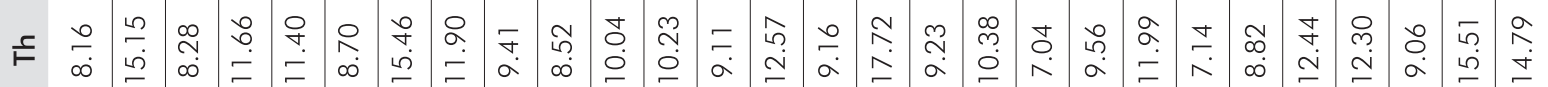
o. $\sum_{2}^{n}$
0
$\frac{5}{5}$
to
$\frac{5}{5}$
$\frac{0}{4}$
3

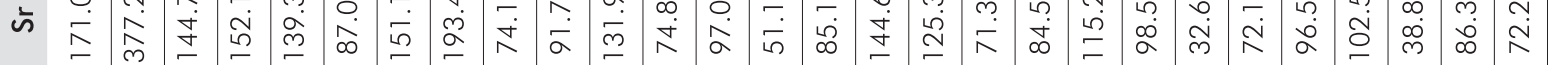
Z

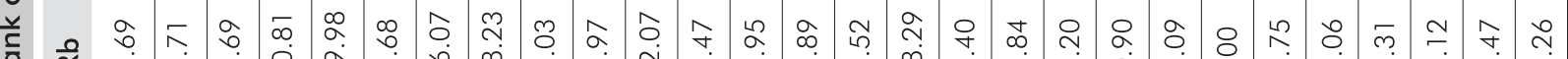

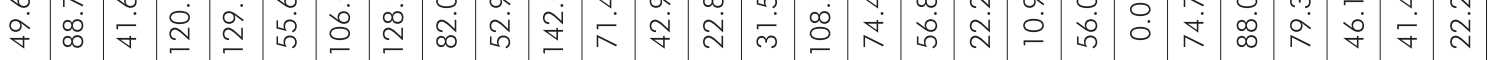

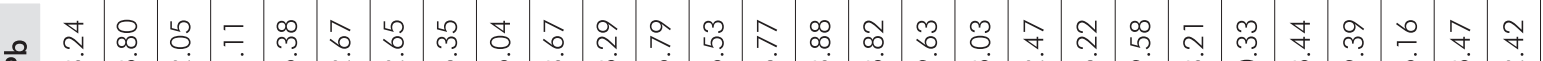

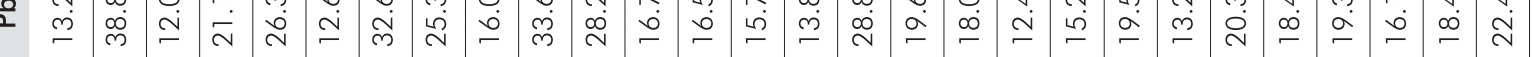

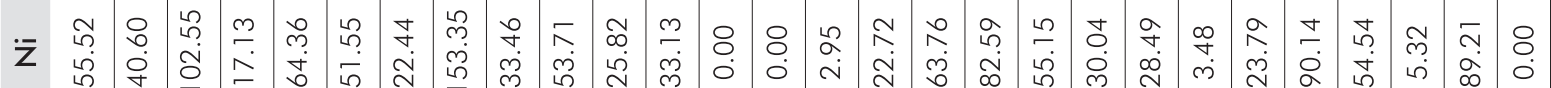

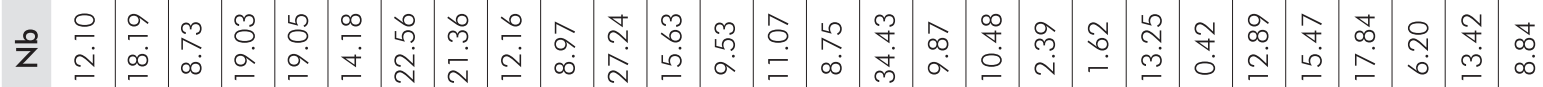

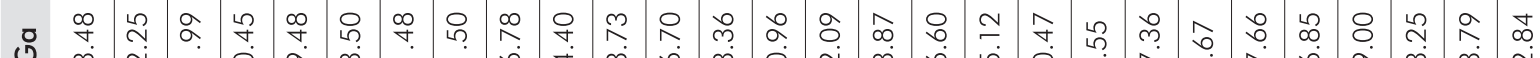

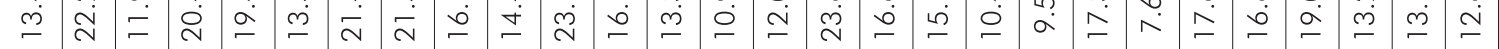

- ㄱำ

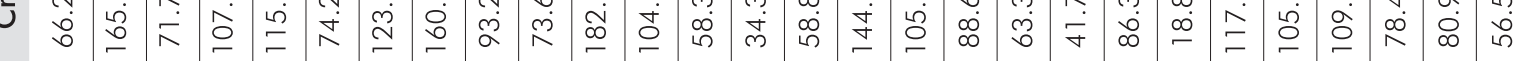

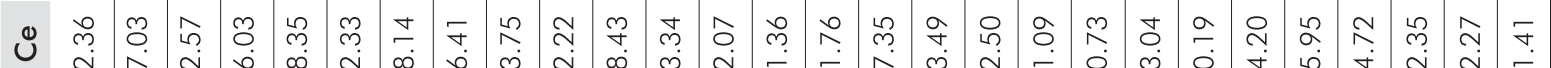

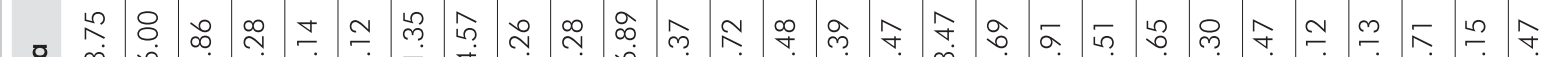

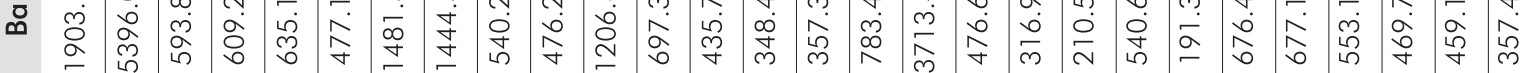

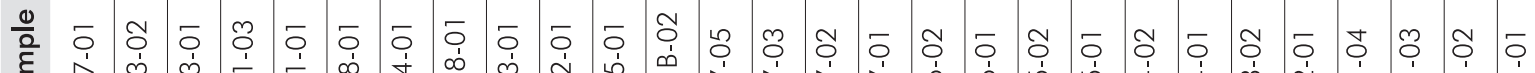

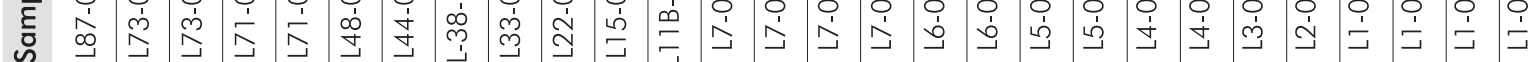




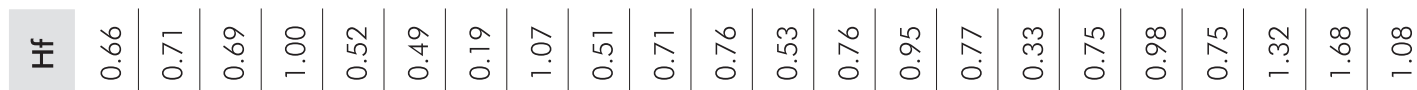

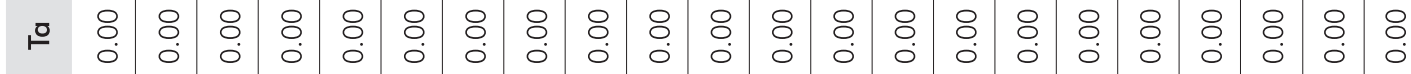

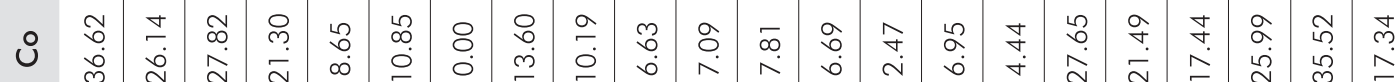

$\supset$ ๖

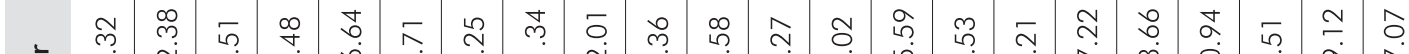

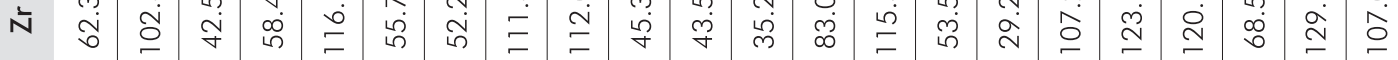

-

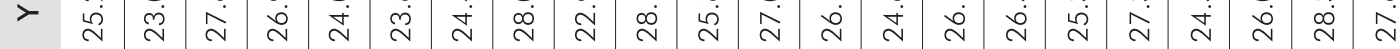

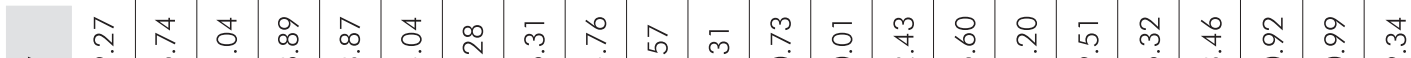

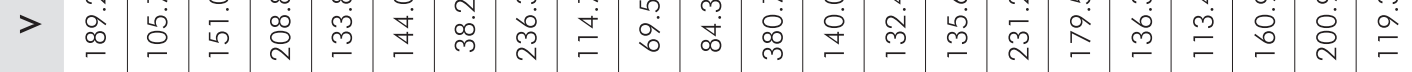

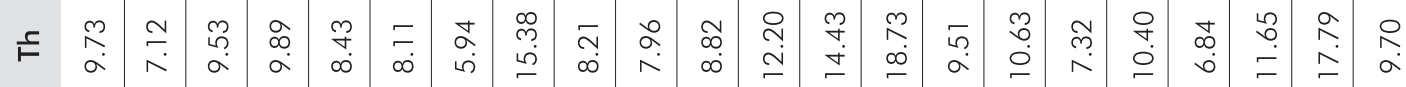

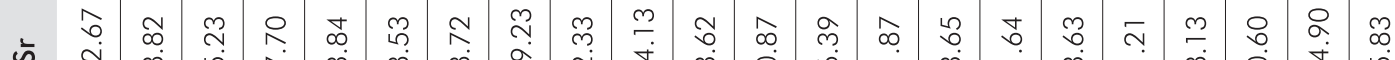

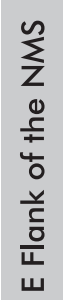

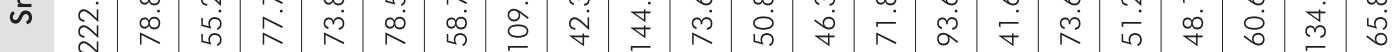

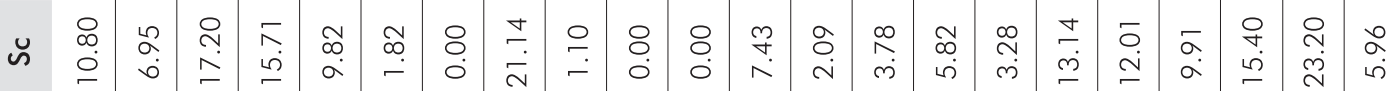

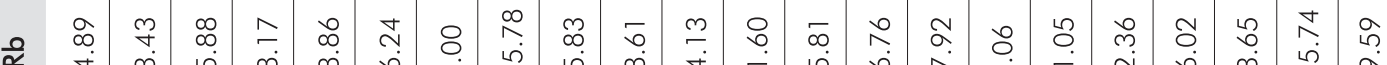

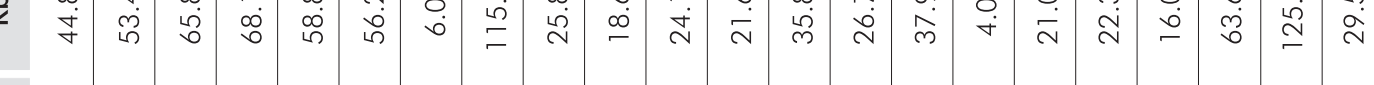

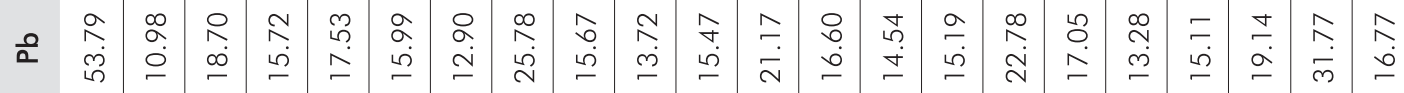

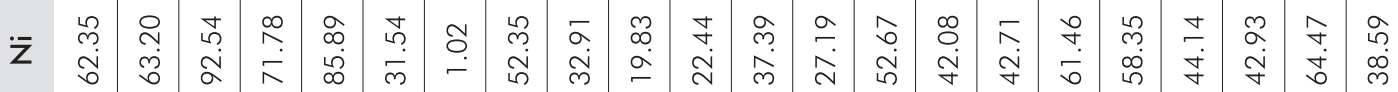

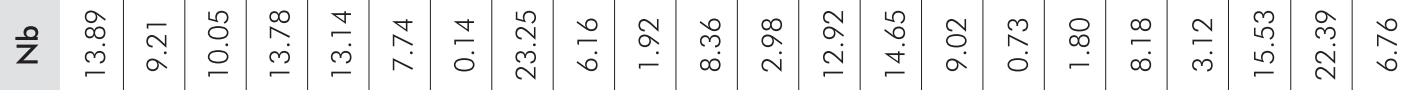

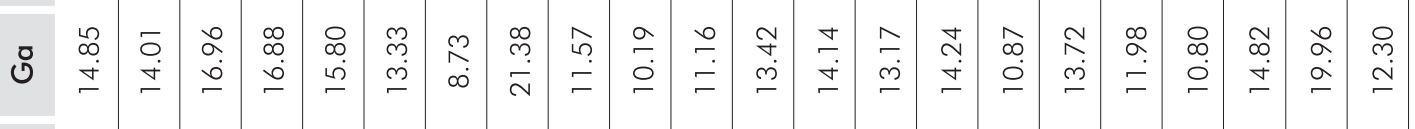

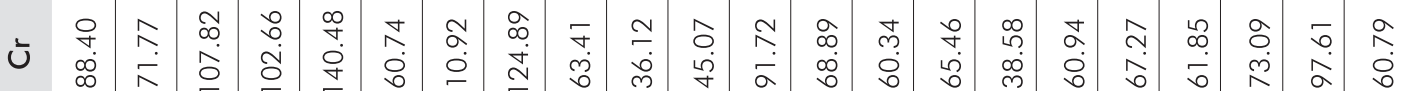

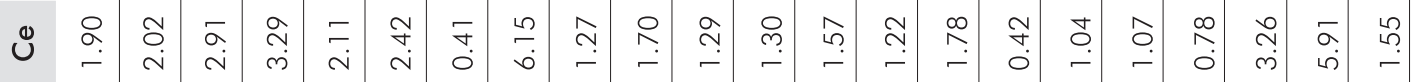

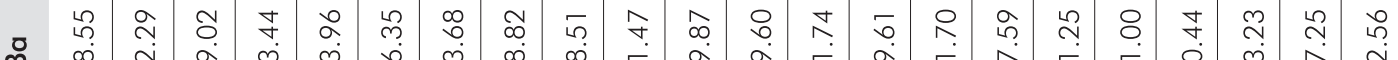

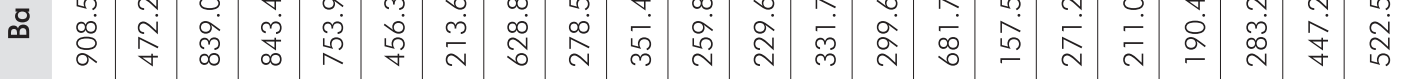

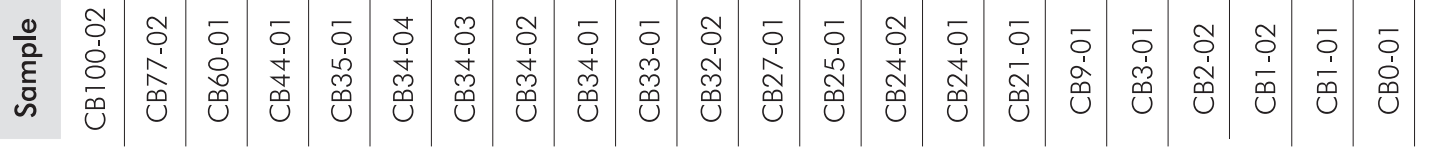


Table 11. Values of rare earth elements (REE) calculated with ICP-MS on the Western Flank of the (NMS).

\begin{tabular}{|c|c|c|c|c|c|c|c|c|c|c|c|c|c|}
\hline \multicolumn{14}{|c|}{ W Flank of the NMS } \\
\hline Sample & $\mathrm{La}$ & $\mathrm{Ce}$ & $\operatorname{Pr}$ & $\mathrm{Nd}$ & Sm & Eu & Gd & $\mathrm{Tb}$ & Dy & Ho & $\mathrm{Er}$ & $\mathrm{Tm}$ & $\mathrm{Yb}$ \\
\hline L87-01 & 28.86 & 62.59 & 6.61 & 26.65 & 5.98 & 1.51 & 4.98 & 0.66 & 3.50 & 0.57 & 1.58 & 0.21 & 1.53 \\
\hline L73-02 & 46.32 & 92.89 & 10.99 & 46.24 & 12.61 & 3.40 & 10.52 & 1.26 & 6.13 & 0.98 & 2.72 & 0.39 & 2.82 \\
\hline L73-01 & 26.73 & 59.12 & 6.57 & 26.53 & 5.56 & 1.24 & 5.17 & 0.66 & 3.48 & 0.57 & 1.50 & 0.19 & 1.23 \\
\hline L71-03 & 37.31 & 76.60 & 8.07 & 30.09 & 5.59 & 1.14 & 4.31 & 0.64 & 2.56 & 0.39 & 1.12 & 0.16 & 1.24 \\
\hline L71-01 & 41.68 & 90.25 & 11.36 & 52.10 & 14.57 & 3.93 & 12.92 & 1.89 & 9.48 & 1.40 & 3.38 & 0.42 & 2.50 \\
\hline Ł48-0 1 & 27.90 & 62.15 & 6.70 & 25.65 & 5.02 & 1.07 & 4.35 & 0.57 & 2.89 & 0.46 & 1.24 & 0.17 & 1.08 \\
\hline L44-0 1 & 51.14 & 98.38 & 10.40 & 39.32 & 7.47 & 1.50 & 6.72 & 0.84 & 4.66 & 0.80 & 2.28 & 0.33 & 2.16 \\
\hline L33-01 & 26.11 & 56.92 & 5.82 & 21.88 & 4.22 & 0.91 & 3.58 & 0.43 & 2.34 & 0.41 & 1.23 & 0.18 & 1.08 \\
\hline L-38-01 & 47.94 & 113.53 & 14.90 & 67.96 & 17.49 & 4.65 & 17.19 & 2.36 & 11.32 & 1.74 & 4.19 & 0.47 & 2.87 \\
\hline L22-01 & 17.80 & 42.41 & 4.26 & 16.49 & 3.59 & 0.79 & 2.87 & 0.37 & 1.88 & 0.30 & 0.79 & 0.11 & 0.70 \\
\hline L15-01 & 36.51 & 71.34 & 7.27 & 26.79 & 5.11 & 1.13 & 3.98 & 0.44 & 2.12 & 0.31 & 0.83 & 0.12 & 0.82 \\
\hline L1 1 B-02 & 48.85 & 89.29 & 9.17 & 33.48 & 6.46 & 1.51 & 6.15 & 0.89 & 5.25 & 1.02 & 2.89 & 0.43 & 2.81 \\
\hline L7-05 & 24.15 & 55.32 & 5.83 & 21.92 & 4.19 & 0.80 & 3.41 & 0.40 & 2.07 & 0.28 & 0.70 & 0.09 & 0.65 \\
\hline L7-03 & 28.82 & 62.39 & 6.52 & 24.49 & 4.71 & 0.83 & 3.78 & 0.44 & 2.09 & 0.31 & 0.73 & 0.09 & 0.60 \\
\hline L7-02 & 21.83 & 50.99 & 5.27 & 19.21 & 3.47 & 0.64 & 2.74 & 0.30 & 1.51 & 0.21 & 0.56 & 0.08 & 0.50 \\
\hline L7-01 & 57.97 & 116.20 & 12.37 & 46.32 & 8.29 & 1.54 & 6.44 & 0.73 & 3.71 & 0.55 & 1.53 & 0.22 & 1.41 \\
\hline L6-02 & 24.87 & 54.30 & 5.98 & 22.54 & 5.74 & 1.45 & 4.07 & 0.52 & 2.64 & 0.44 & 1.22 & 0.18 & 1.10 \\
\hline L6-01 & 24.38 & 56.91 & 6.13 & 24.47 & 5.22 & 1.06 & 4.57 & 0.61 & 3.08 & 0.50 & 1.43 & 0.19 & 1.10 \\
\hline L5-02 & 17.26 & 42.78 & 4.47 & 17.01 & 3.59 & 0.81 & 2.99 & 0.41 & 2.01 & 0.31 & 0.79 & 0.11 & 0.75 \\
\hline L5-0 1 & 20.23 & 51.07 & 5.27 & 20.10 & 3.94 & 0.79 & 3.16 & 0.41 & 1.83 & 0.26 & 0.60 & 0.08 & 0.45 \\
\hline L4-02 & 29.52 & 60.92 & 6.45 & 24.34 & 4.62 & 0.89 & 3.88 & 0.49 & 2.62 & 0.44 & 1.20 & 0.17 & 1.04 \\
\hline$\lfloor 4-01$ & 19.85 & 51.49 & 5.11 & 19.67 & 3.84 & 0.71 & 3.03 & 0.35 & 1.56 & 0.19 & 0.44 & 0.05 & 0.35 \\
\hline L3-02 & 32.47 & 72.94 & 8.22 & 32.95 & 6.98 & 1.55 & 6.02 & 0.79 & 4.22 & 0.71 & 1.91 & 0.23 & 1.59 \\
\hline L2-0 1 & 30.89 & 62.92 & 6.82 & 25.51 & 4.97 & 1.01 & 4.42 & 0.55 & 3.24 & 0.53 & 1.50 & 0.21 & 1.41 \\
\hline L1-04 & 41.97 & 85.99 & 9.55 & 36.54 & 7.60 & 1.57 & 6.03 & 0.77 & 4.60 & 0.59 & 1.55 & 0.22 & 1.41 \\
\hline L1-03 & 20.27 & 46.20 & 4.57 & 16.12 & 2.98 & 0.56 & 2.25 & 0.26 & 1.24 & 0.21 & 0.57 & 0.09 & 0.56 \\
\hline L1-02 & 39.01 & 83.08 & 9.13 & 35.27 & 7.05 & 1.26 & 6.08 & 0.77 & 3.95 & 0.62 & 1.64 & 0.22 & 1.48 \\
\hline L1-01 & 25.37 & 58.12 & 5.95 & 22.33 & 4.40 & 0.76 & 3.41 & 0.40 & 1.95 & 0.31 & 0.89 & 0.13 & 0.96 \\
\hline
\end{tabular}


Table 12. Values of rare earth elements (REE) calculated with ICP-MS on the Eastern Flank of the (NMS).

\begin{tabular}{|c|c|c|c|c|c|c|c|c|c|c|c|c|c|}
\hline \multicolumn{14}{|c|}{ E Flank of the NMS } \\
\hline Sample & La & $\mathrm{Ce}$ & $\operatorname{Pr}$ & $\mathrm{Nd}$ & Sm & Eu & Gd & $\mathrm{Tb}$ & Dy & Ho & $\mathrm{Er}$ & $\mathrm{Tm}$ & $\mathrm{Yb}$ \\
\hline CB100-02 & 83.12 & 149.17 & 15.97 & 61.53 & 8.69 & 1.52 & 6.40 & 0.64 & 3.16 & 0.42 & 1.12 & 0.15 & 0.98 \\
\hline CB77-02 & 20.48 & 48.37 & 4.95 & 18.34 & 3.43 & 0.73 & 2.71 & 0.33 & 1.81 & 0.28 & 0.77 & 0.11 & 0.75 \\
\hline CB60-01 & 33.02 & 71.61 & 8.40 & 35.69 & 7.96 & 2.02 & 7.57 & 1.05 & 5.65 & 0.97 & 2.56 & 0.35 & 2.14 \\
\hline CB44-01 & 23.62 & 55.30 & 6.17 & 24.64 & 5.04 & 1.06 & 3.85 & 0.44 & 2.05 & 0.30 & 0.76 & 0.10 & 0.62 \\
\hline CB35-01 & 21.81 & 53.19 & 5.90 & 24.55 & 5.65 & 1.38 & 4.84 & 0.67 & 3.53 & 0.57 & 1.51 & 0.22 & 1.39 \\
\hline CB34-04 & 29.61 & 65.55 & 7.27 & 29.03 & 6.28 & 1.46 & 5.72 & 0.73 & 3.84 & 0.60 & 1.72 & 0.22 & 1.40 \\
\hline CB34-03 & 14.56 & 35.55 & 3.49 & 12.21 & 2.18 & 0.40 & 1.86 & 0.21 & 1.01 & 0.14 & 0.31 & 0.04 & 0.22 \\
\hline CB34-02 & 43.46 & 86.98 & 9.46 & 37.06 & 7.27 & 1.39 & 6.04 & 0.74 & 3.69 & 0.58 & 1.50 & 0.19 & 1.16 \\
\hline CB34-01 & 23.91 & 53.33 & 5.51 & 20.84 & 3.82 & 0.72 & 2.98 & 0.35 & 1.70 & 0.25 & 0.64 & 0.08 & 0.52 \\
\hline CB33-01 & 21.07 & 51.34 & 5.42 & 20.80 & 4.31 & 0.87 & 4.03 & 0.52 & 2.78 & 0.45 & 1.17 & 0.15 & 0.94 \\
\hline CB32-02 & 21.94 & 50.76 & 5.37 & 20.67 & 4.15 & 0.84 & 3.55 & 0.48 & 2.46 & 0.41 & 1.07 & 0.13 & 0.89 \\
\hline CB27-01 & 24.96 & 58.60 & 6.21 & 23.31 & 4.42 & 0.87 & 3.69 & 0.46 & 2.30 & 0.34 & 0.92 & 0.12 & 0.77 \\
\hline CB25-01 & 31.24 & 70.72 & 7.58 & 29.15 & 5.79 & 1.05 & 4.50 & 0.52 & 2.47 & 0.37 & 0.96 & 0.13 & 0.76 \\
\hline CB24-02 & 44.68 & 92.07 & 10.14 & 39.13 & 7.17 & 1.09 & 5.63 & 0.65 & 3.05 & 0.44 & 1.12 & 0.15 & 0.92 \\
\hline CB24-01 & 24.44 & 55.96 & 6.10 & 23.90 & 4.89 & 0.97 & 4.20 & 0.52 & 2.71 & 0.40 & 1.07 & 0.14 & 0.93 \\
\hline CB21-01 & 19.61 & 52.63 & 5.20 & 19.64 & 3.98 & 0.76 & 3.67 & 0.51 & 2.76 & 0.45 & 1.18 & 0.16 & 1.00 \\
\hline CB9-01 & 16.91 & 47.71 & 5.06 & 21.73 & 5.42 & 1.35 & 4.91 & 0.73 & 3.97 & 0.64 & 1.57 & 0.20 & 1.18 \\
\hline CB3-01 & 23.83 & 61.95 & 7.27 & 31.63 & 7.74 & 2.01 & 7.39 & 1.11 & 6.17 & 1.02 & 2.47 & 0.31 & 1.95 \\
\hline CB2-02 & 15.59 & 40.85 & 4.51 & 18.09 & 4.20 & 0.93 & 3.81 & 0.56 & 3.01 & 0.50 & 1.25 & 0.16 & 1.01 \\
\hline CB 1-02 & 28.62 & 68.58 & 7.23 & 27.84 & 5.76 & 1.20 & 5.07 & 0.66 & 3.64 & 0.62 & 1.59 & 0.22 & 1.34 \\
\hline CB1-01 & 41.80 & 89.34 & 9.68 & 36.12 & 6.45 & 1.24 & 5.52 & 0.71 & 4.02 & 0.69 & 1.90 & 0.27 & 1.78 \\
\hline CBO-01 & 20.64 & 52.24 & 5.97 & 24.84 & 5.59 & 1.28 & 5.43 & 0.77 & 4.38 & 0.75 & 1.83 & 0.24 & 1.47 \\
\hline
\end{tabular}


